Prepared in cooperation with the North Dakota State Water Commission

Continuous Water-Quality Monitoring and Regression Analysis to Estimate Constituent Concentrations and Loads in the Sheyenne River, North Dakota, 1980-2006

Scientific Investigations Report 2007-5153 


\section{Continuous Water-Quality Monitoring and Regression Analysis to Estimate Constituent Concentrations and Loads in the Sheyenne River, North Dakota, 1980-2006}

By Karen R. Ryberg

Prepared in cooperation with the North Dakota State Water Commission

Scientific Investigations Report 2007-5153 


\section{U.S. Department of the Interior DIRK KEMPTHORNE, Secretary \\ U.S. Geological Survey \\ P. Patrick Leahy, Acting Director}

\section{U.S. Geological Survey, Reston, Virginia: 2007}

For product and ordering information:

World Wide Web: http://www.usgs.gov/pubprod

Telephone: 1-888-ASK-USGS

For more information on the USGS--the Federal source for science about the Earth, its natural and living resources, natural hazards, and the environment:

World Wide Web: http://www.usgs.gov

Telephone: 1-888-ASK-USGS

Any use of trade, product, or firm names is for descriptive purposes only and does not imply endorsement by the U.S. Government.

Although this report is in the public domain, permission must be secured from the individual copyright owners to reproduce any copyrighted materials contained within this report.

Suggested citation:

Ryberg, K.R., 2007, Continuous water-quality monitoring and regression analysis to estimate constituent concentrations and loads in the Sheyenne River, North Dakota, 1980-2006: U.S. Geological Survey Scientific Investigations Report 2007-5153, 22 p. 


\section{Contents}

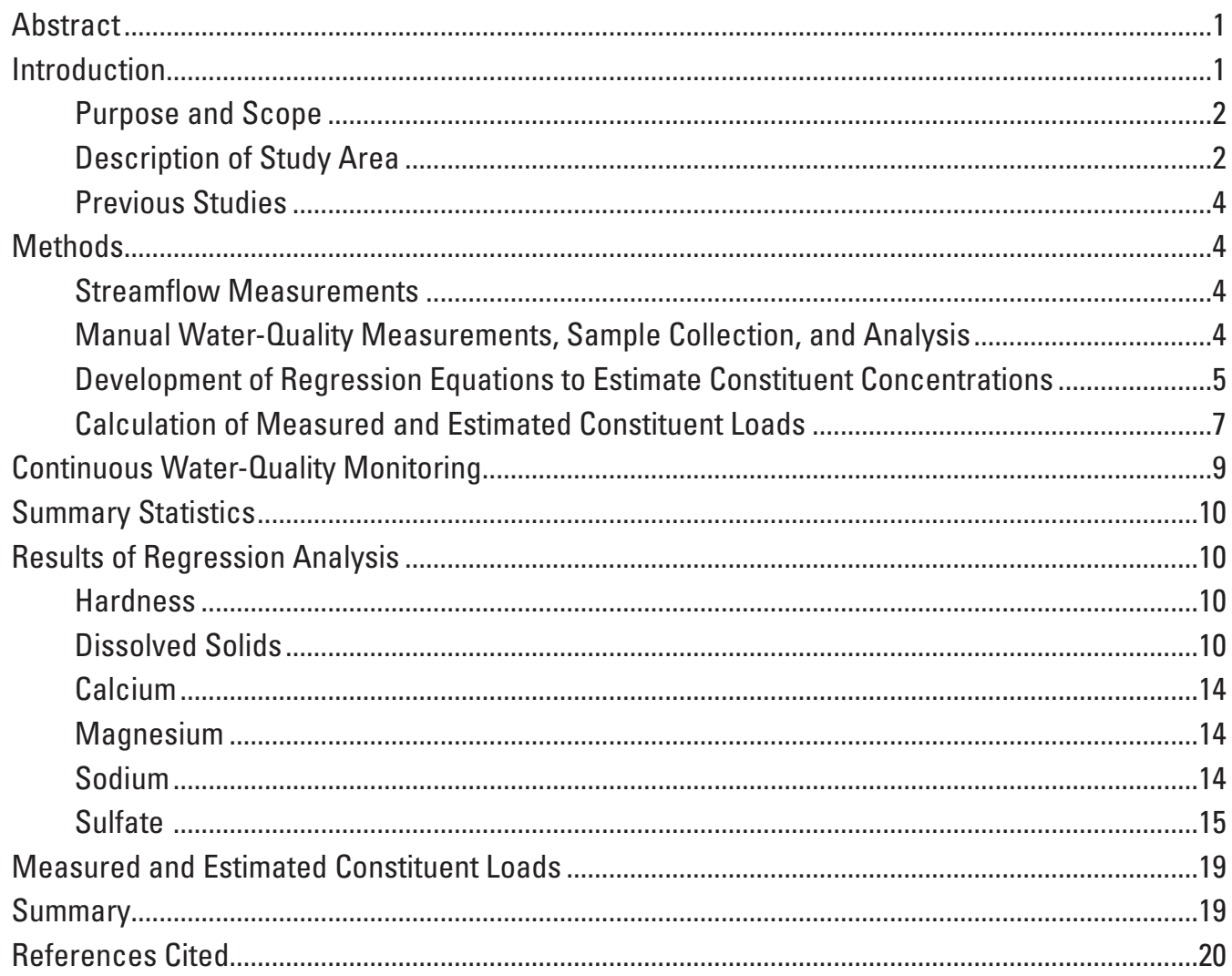

\section{Figures}

1. Map showing location of the seven sampling sites on the Sheyenne River, N. Dak ........3

2-5. Graphs showing:

2. Comparison of measured and estimated sodium concentrations in the Sheyenne River, N. Dak., at site 1

3. Predicted sulfate concentration, 90-percent prediction interval, and individual samples used in regression analyses for sites 2 and 3 on the Sheyenne River, N. Dak., 2005-06

4. Predicted sulfate concentration, 90-percent prediction interval, and individual samples used in regression analyses for sites 5,6 , and 7 on the Sheyenne River, N. Dak., 2000-2006

5. Comparison of measured and estimated sulfate loads for site 7 on the Sheyenne River, N. Dak., 1997-2006 


\section{Tables}

1. Sites used for regression analysis, Sheyenne River, N. Dak., 1980-2006

2. Constituents estimated using regression equations for the Sheyenne River, N. Dak., 1980-2006

3. Possible surrogate physical properties, or explanatory variables, used to develop regression relations to estimate constituent concentrations in Sheyenne River, N. Dak., 1980-2006 .7

4. Conversion factors used in calculation of measured and estimated loads .9

5. Summary of statistics for water-quality sampling sites on the Sheyenne River, N. Dak., 1980-2006

6. Regression equations for estimates of hardness in the Sheyenne River, N. Dak., 1980-2006

7. Regression equations for estimates of dissolved solids in the Sheyenne River, N. Dak., 1980-2006.

8. Regression equations for estimates of calcium in the Sheyenne River, N. Dak., 1980-2006

9. Regression equations for estimates of magnesium in the Sheyenne River, N. Dak., 1980-2006

10. Regression equations for estimates of sodium in the Sheyenne River, N. Dak., 1980-2006

11. Regression equations for estimates of sulfate in the Sheyenne River, N. Dak., 1980-2006 


\section{Conversion Factors, Abbreviations, and Datum}

\begin{tabular}{lcl}
\hline Multiply & By & To obtain \\
\hline \multicolumn{1}{l}{ foot (ft) } & Length & \\
yard (yd) & 0.3048 & meter $(\mathrm{m})$ \\
mile (mi) & .9144 & meter $(\mathrm{m})$ \\
\hline & 1.609 & kilometer $(\mathrm{km})$ \\
\hline square mile $\left(\mathrm{mi}^{2}\right)$ & Area & \\
square mile $\left(\mathrm{mi}^{2}\right)$ & 259.0 & hectare $(\mathrm{ha})$ \\
& 2.590 & square kilometer $\left(\mathrm{km}^{2}\right)$ \\
\hline cubic foot per second $(\mathrm{ft} 3 / \mathrm{s})$ & Flow rate & \\
\hline & 0.02832 & cubic meter per second $\left(\mathrm{m}^{3} / \mathrm{s}\right)$ \\
\hline pound, avoirdupois $(\mathrm{lb})$ & Mass & kilogram $(\mathrm{kg})$ \\
\hline
\end{tabular}

Temperature in degrees Celsius $\left({ }^{\circ} \mathrm{C}\right)$ may be converted to degrees Fahrenheit $\left({ }^{\circ} \mathrm{F}\right)$ as follows:

$$
{ }^{\circ} \mathrm{F}=\left(1.8 x^{\circ} \mathrm{C}\right)+32 \text {. }
$$

Temperature in degrees Fahrenheit $\left({ }^{\circ} \mathrm{F}\right)$ may be converted to degrees Celsius $\left({ }^{\circ} \mathrm{C}\right)$ as follows:

$$
{ }^{\circ} \mathrm{C}=\left({ }^{\circ} \mathrm{F}-32\right) / 1.8 \text {. }
$$

Specific conductance is given in microsiemens per centimeter at 25 degrees Celsius $(\mu \mathrm{S} / \mathrm{cm}$ at $\left.25^{\circ} \mathrm{C}\right)$.

Concentrations of chemical constituents in water are given in milligrams per liter (mg/L).

Horizontal coordinate information is referenced to North American Datum of 1927 (NAD 27). 


\title{
Continuous Water-Quality Monitoring and Regression Analysis to Estimate Constituent Concentrations and Loads in the Sheyenne River, North Dakota, 1980-2006
}

\author{
By Karen R. Ryberg
}

\begin{abstract}
This report presents the results of a study by the U.S. Geological Survey, done in cooperation with the North Dakota State Water Commission, to estimate water-quality constituent concentrations at seven sites on the Sheyenne River, N. Dak. Regression analysis of water-quality data collected in 1980-2006 was used to estimate concentrations for hardness, dissolved solids, calcium, magnesium, sodium, and sulfate. The explanatory variables examined for the regression relations were continuously monitored streamflow, specific conductance, and water temperature. For the conditions observed in 1980-2006, streamflow was a significant explanatory variable for some constituents. Specific conductance was a significant explanatory variable for all of the constituents, and water temperature was not a statistically significant explanatory variable for any of the constituents in this study.

The regression relations were evaluated using common measures of variability, including $R^{2}$, the proportion of variability in the estimated constituent concentration explained by the explanatory variables and regression equation. $R^{2}$ values ranged from 0.784 for calcium to 0.997 for dissolved solids. The regression relations also were evaluated by calculating the median relative percentage difference $(R P D)$ between measured constituent concentration and the constituent concentration estimated by the regression equations. Median $R P D$ s ranged from 1.7 for dissolved solids to 11.5 for sulfate. The regression relations also may be used to estimate daily constituent loads.

The relations should be monitored for change over time, especially at sites 2 and 3 which have a short period of record. In addition, caution should be used when the Sheyenne River is affected by ice or when upstream sites are affected by isolated storm runoff. Almost all of the outliers and highly influential samples removed from the analysis were made during periods when the Sheyenne River might be affected by ice.
\end{abstract}

\section{Introduction}

The U.S. Geological Survey (USGS) continuously records gage height, specific conductance, and water temperature at seven gaging sites on the Sheyenne River (fig. 1; table 1) in cooperation with several State and Federal agencies. Data from the continuous real-time water-quality monitors on the Sheyenne River are available on the Internet from the USGS National Water Information System (NWISWeb, http://waterdata.usgs.gov/nd/nwis). Continuous monitoring provides valuable information and may identify important variability that may not be evident in discrete water-quality sampling schemes. This information could be used to estimate concentrations of other water-quality constituents of interest, such as sulfate.

Devils Lake, in the adjoining Devils Lake Basin (fig. 1), began flooding in the 1990s and continues to the present (2007). According to the North Dakota State Water Commission's Devils Lake Quick Facts [n.d.], Devils Lake flooding "has destroyed hundreds of homes and businesses and inundated thousands of acres of productive farmland. The State of North Dakota and the U.S. Government have spent over $\$ 450$ million dollars in flood mitigation efforts including moving roads, rail and power lines, and building dikes." The State of North Dakota has constructed an outlet to allow water from Devils Lake to flow into the Sheyenne River. The maximum outlet discharge is based in part on the sulfate concentration at the Sheyenne River downstream from the outlet insertion point (North Dakota State Water Commission [n.d.], Devils Lake Flooding-Outlet). Many water-quality stakeholders are concerned about the effect that water from Devils Lake might have on the Sheyenne River. The Sheyenne River is a tributary of the Red River of the North (Red River), which flows into Canada, therefore, the water quality of the Sheyenne River is of interest to users of the Red River in North Dakota, Minnesota, and Canada. 
Table 1. Sites used for regression analysis, Sheyenne River, N. Dak., 1980-2006.

[--, not applicable]

\begin{tabular}{|c|c|c|c|c|c|}
\hline $\begin{array}{l}\text { Site number } \\
\text { (figure 1) }\end{array}$ & $\begin{array}{l}\text { U.S. Geological } \\
\text { Survey } \\
\text { station number }\end{array}$ & $\begin{array}{c}\text { North Dakota State } \\
\text { Water Commission } \\
\text { location number }\end{array}$ & U.S. Geological Survey station name & Latitude & Longitude \\
\hline 1 & 05054500 & -- & Sheyenne River above Harvey, N. Dak. & $47^{\circ} 42^{\prime} 10^{\prime \prime}$ & $99^{\circ} 56^{\prime} 55^{\prime \prime}$ \\
\hline 2 & 05055300 & 15106807 & $\begin{array}{l}\text { Sheyenne River above Devils Lake State outlet } \\
\text { near Flora, N. Dak. }\end{array}$ & $47^{\circ} 54^{\prime} 28^{\prime \prime}$ & $99^{\circ} 24^{\prime} 57^{\prime \prime}$ \\
\hline 4 & 05056000 & -- & Sheyenne River near Warwick, N. Dak. & $47^{\circ} 48^{\prime} 20^{\prime \prime}$ & $98^{\circ} 42^{\prime} 57^{\prime} \prime$ \\
\hline 5 & 05057000 & -- & Sheyenne River near Cooperstown, N. Dak. & $47^{\circ} 25^{\prime} 58^{\prime \prime}$ & $98^{\circ} 01^{\prime} 38^{\prime \prime}$ \\
\hline 6 & 05058000 & -- & Sheyenne River below Baldhill Dam, N. Dak. & $47^{\circ} 02^{\prime} 02^{\prime \prime}$ & $98^{\circ} 05^{\prime} 00^{\prime \prime}$ \\
\hline 7 & 05059300 & -- & $\begin{array}{l}\text { Sheyenne River above Sheyenne River Diversion } \\
\text { near Horace, N. Dak. }\end{array}$ & $46^{\circ} 45^{\prime} 01^{\prime \prime}$ & $96^{\circ} 55^{\prime} 35^{\prime \prime}$ \\
\hline
\end{tabular}

For the study described in this report, the USGS, in cooperation with the North Dakota State Water Commission (NDSWC), analyzed the data collected at the seven sites on the Sheyenne River to determine whether streamflow and the continuously recorded physical properties could act as surrogates to estimate water-quality constituents that are important indicators of surface-water quality. The methods used in this study replicate those previously used in North Dakota for the Red River at Fargo (Ryberg, 2006) and in Kansas (Christensen and others, 2000; Christensen, 2001; Rasmussen and others, 2005; and Christensen and others, 2006) and may be replicated for other sites in North Dakota and the Nation to monitor water quality.

Estimation of water-quality constituents on the basis of surrogates provides several benefits. Although periodic Sheyenne River water-quality samples are collected manually, the delay associated with laboratory analysis does not permit immediate identification of undesirable levels of constituents. A relation between manually collected water-quality samples and continuously recorded water-quality physical properties allows immediate identification of potential water-quality problems. Examination of streamflow and physical properties of water that act as surrogates for constituents of interest also helps optimize visits for the collection of water-quality samples. For example, if specific conductance is used as a surrogate for estimating sulfate, it is desirable to collect water-quality samples representative of the range of specificconductance values possible for the Sheyenne River at each site. In addition, the continuous estimation of water-quality information is useful in tracking changes in water quality as they occur.

\section{Purpose and Scope}

This report presents the results of regression analysis of water-quality constituents for seven sites on the Sheyenne River, N. Dak., using manually collected water-quality data and continuously recorded streamflow and physical property data from seven sites on the Sheyenne River. The data were collected during 1980-2006. The report provides regression equations that can be used to estimate concentrations and loads for hardness, dissolved solids, calcium, magnesium, sodium, and sulfate.

\section{Description of Study Area}

The Sheyenne River (fig. 1) originates in Sheridan County in central North Dakota and flows through southeastern North Dakota, ultimately emptying into the Red River, north of Fargo. The Sheyenne River has a drainage area of about 6,910 square miles, not including the closed Devils Lake Basin (Emerson, 2005).

At times there is no flow in the upper reaches of the Sheyenne River. Flows in lower reaches are regulated partly by release from Baldhill Dam, approximately 12 miles north of Valley City. Baldhill Dam, completed in 1951, provides water supply, flood control, recreation, and wildlife habitat (U.S. Army Corps of Engineers, 2005).

Site 1 is USGS gaging station 05054500 Sheyenne River above Harvey, N. Dak. and is located 2 miles upstream from an unnamed tributary, and 4.5 miles south of Harvey. The recording gage was established in September 1955. Periodic water-quality sampling began at this site in 1971. Specific 


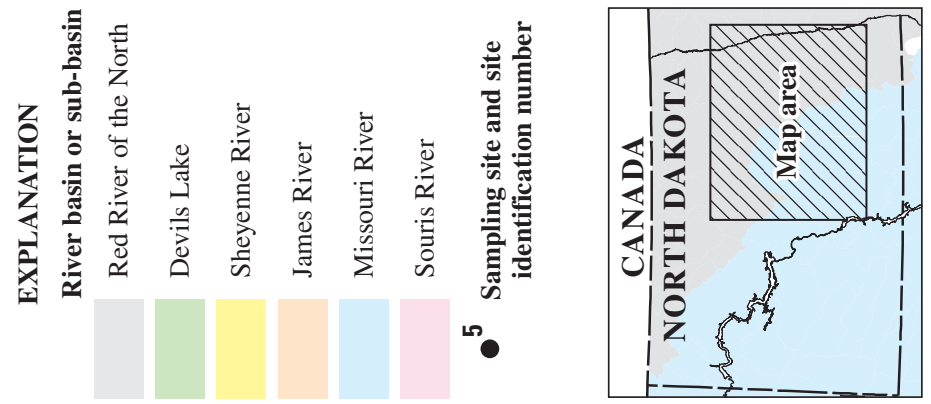

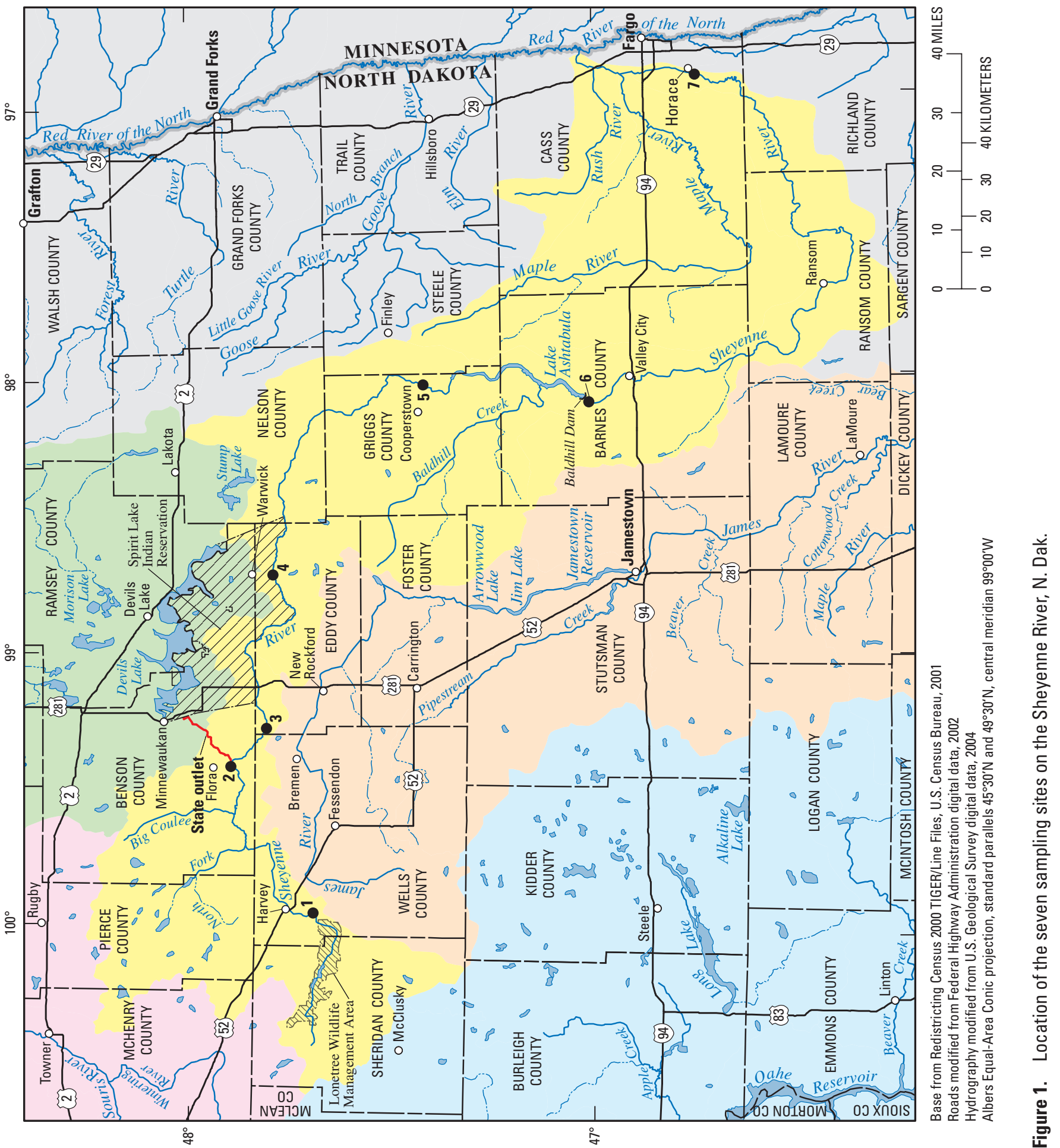


conductance and water temperature have been continuously recorded since May 2006. This gage records little or no flow most winters and is heavily affected by ice (L.A. Cottengaim, USGS, station description, unpub. data, 2007).

Site 2 is USGS gaging station 05055300 Sheyenne River above Devils Lake State outlet near Flora, N. Dak. The gage began recording stage, specific conductance, and water temperature in October 2004, 3.5 mi southeast of Flora (R.A. Nustad, USGS, station description, unpub. data, 2006). Periodic water-quality sampling by the USGS and the NDSWC began at this site in 2005. Gage height is affected by ice and by growth of vegetation in the channel during periods of low flow (P.M. Scarpari, USGS, station analysis, unpub. data, 2006).

Site 3 is USGS gaging station 05055400 Sheyenne River below Devils Lake State outlet near Bremen, N. Dak. The seasonal (operated April through November) recording gage was established in March 2005, 10 mi northeast of Bremen. Specific conductance and water temperature have been continuously recorded, seasonally, since April 2005. Periodic waterquality sampling by the USGS and the NDSWC began at this site in 2005 (R.A. Nustad, USGS, station description, unpub. data, 2007).

Site 4 is USGS gaging station 05056000 Sheyenne River near Warwick, N. Dak. The recording gage was installed November 1949, 0.25 mi west and $3.3 \mathrm{mi}$ south of Warwick. Periodic water-quality sampling at this site began in 1951. Specific conductance and water temperature have been continuously recorded since May 4, 2006 (P.M. Scarpari, USGS, station description, unpub. data, 2007).

Site 5 is USGS gaging station 05057000 Sheyenne River near Cooperstown, N. Dak. A recording gage was established in 1950 and moved to the current location in October 1985, at Ueland Dam, 5 mi east of Cooperstown. Periodic water-quality sampling at this site began in 1959. Specific conductance and water temperature have been continuously recorded since June 1997. Records may be poor during winter periods (R.A. Nustad, USGS, station description, unpub. data, 2006).

Site 6 is USGS gaging station 05058000 Sheyenne River below Baldhill Dam, N. Dak. The gage was established in 1949 and has been moved several times. Since September 2000, the gage has been located $0.1 \mathrm{mi}$ downstream from Baldhill Dam, approximately $0.25 \mathrm{mi}$ upstream from a bridge. Periodic water-quality sampling at this site began in 1959. Specific conductance and water temperature have been continuously recorded since April 1997. The station is generally not affected by ice because of releases from Baldhill Dam (R.A. Nustad, USGS, station description, unpub. data, 2007).

Site 7 is USGS gaging station 05059300 Sheyenne River above Sheyenne River Diversion near Horace, N. Dak. The recording gage was established in October 1992, $1 \mathrm{mi}$ southwest of Horace, upstream from the diversion structure. Periodic water-quality sampling began at this site in 1992. Specific conductance and water temperature have been continuously recorded since June 1997. Gage height is affected by ice through most of the winter months and flow is regulated to a large degree by Baldhill Dam, approximately $230 \mathrm{mi}$ upstream (P.M. Scarpari, USGS, station description, unpub. data, 2007).

Additional information about these sites is available online at $h t t p: / / w a t e r d a t a . u s g s . g o v / n d /$ nwis/nwisman/?site_ $n o=X X X X X X X X$, where $\mathrm{XXXXXXXX}$ is the 8-digit USGS station number listed in table 1.

\section{Previous Studies}

Regression relations have been developed previously for sites on the Sheyenne River to estimate monthly mean constituent concentrations (Guenthner, 1991; Williams-Sether, 2004). Guenthner's study (1991) preceded continuous recording of specific conductance and water temperature; therefore, the only continuously recorded variable available for regression analysis was streamflow. The only continuously recorded variable used by Williams-Sether (2004) was streamflow.

Regression analysis to estimate constituent concentrations and loads was used by Ryberg (2006) for the Red River at Fargo, N. Dak., and has been used for numerous sites in Kansas (Christensen and others, 2000; Christensen, 2001; Rasmussen and others, 2005; and Christensen and others, 2006).

\section{Methods}

Data collection and analysis methods have varied over time and from site to site. This section describes how streamflow was measured, water-quality samples were collected and analyzed, and data were interpreted for this study.

\section{Streamflow Measurements}

Stage, or gage height, was measured to the nearest $0.01 \mathrm{ft}$ at all stations. The data for all stations are stored and publicly available in the National Water Information System: Web Interface (NWISWeb), http://waterdata.usgs.gov/nd/nwis.

Methods used to determine streamflow are described in Buchanan and Somers (1969). Streamflow measurements were made periodically at each station. A stage-streamflow relation was developed on the basis of streamflow measurements and the stage of the stream at the time of measurement (Kennedy, 1984), and this relation was used to compute a continuous record of streamflow (Kennedy, 1983).

\section{Manual Water-Quality Measurements, Sample Collection, and Analysis}

During the collection of water-quality samples, physical properties of water, including specific conductance and water temperature, were measured. USGS water-quality samples were collected manually according to methods described in USGS techniques manuals (U.S. Geological Survey, variously 
dated). After the manually measured physical property and water-quality data were checked and approved by the USGS, they were made publicly available in NWISWeb at $h t t p: / / n w i s$. waterdata.usgs.gov/nd/nwis/qwdata.

Water-quality samples collected by the USGS were analyzed by the NDSWC Laboratory or the North Dakota Department of Health Laboratory. The NDSWC Laboratory and the North Dakota Department of Health Laboratory followed U.S. Environmental Protection Agency approved methods and procedures. The NDSWC Laboratory closed July 2003. Water-quality samples were analyzed by the North Dakota Department of Health Laboratory using standardized methods (North Dakota Department of Health, 2003b) and quality assurance procedures (North Dakota Department of Health, 2003a). External agencies and customer organizations audited the North Dakota Department of Health Laboratory to assure the laboratory analytical methods and qualityassurance/quality-control procedures. The U.S. Environmental Protection Agency reviewed the laboratory procedures about every 3 years, and the Branch of Quality Systems of the USGS periodically reviewed the laboratory procedures.

Water-quality samples collected by the NDSWC were analyzed by the North Dakota Department of Health Laboratory using standardized methods (North Dakota Department of Health, 2003b) and quality-assurance procedures (North Dakota Department of Health, 2003a). Data are stored in the NDSWC's Ground and Surface Water database available online at http://www.swc.nd.gov/4dlink2/4dcgi/ wellsearchform/Map\%20and\%20Data\%20Resources. In the NDSWC database, the NDSWC identifies site 2, Sheyenne River above Devils Lake State outlet near Flora, N. Dak., with the location number 15106807, and site 3, Sheyenne River below Devils Lake State outlet near Bremen, N. Dak., with the location number 15006708. Only data from the NDSWC database that had field specific-conductance measurements were used for this report. The NDSWC's Ground and Surface Water database does not provide streamflow with the waterquality data. Therefore, the USGS automated data processing system (ADAPS, Revision NWIS-4.6.0-40) was used to obtain interpolated unit values for streamflow. ADAPS stores the streamflow values for the USGS Sheyenne River gaging sites in one-hour increments and interpolates a streamflow value based on the Water Commission's specified sampling time and the streamflow for the closest hour before and the closest hour after the sampling time.

Water-quality data were collected as long ago as 1951. However, using data from such a long period of time introduces many sources of variability. Field and laboratory methods change over time and three different laboratories were used for some sites with long periods of record (sites 1 , 4, 5, and 6; fig. 1). In examining scatterplots and regression diagnostic plots, an inordinate number of outliers appeared in the data from the 1970s (data not shown). Many of the potential outliers may have been transposed during data entry, but the original data are no longer available to check. Water temperature was identified as a statistically significant explanatory variable for many constituents, but this was an unexpected finding and did not follow from the results of previous studies (Christensen and others, 2000; Christensen, 2001; Ryberg, 2006). By limiting water-quality data to samples collected beginning in 1980 through 2006, some of the variability in laboratories, two rather than three analyzing laboratories, was eliminated, the number of potential outliers was reduced, and water temperature was no longer statistically significant as an explanatory variable for constituent concentration.

Data were removed from the regression analysis based on streamflow to eliminate samples collected from pooled and stagnant water. For sites 4 and 5, only water-quality samples with an associated streamflow of at least $5.00 \mathrm{ft}^{3} / \mathrm{s}$ were used, based on structures at the gage and river characteristics (R.F. Lundgren and W.C. Damschen, USGS, oral commun., 2007). Site 1 , generally having streamflow or being dry, is not as prone to pooling as sites 4 and 5 (R.F. Lundgren and W.C. Damschen, USGS, oral commun., 2007); however, the point of zero flow at site 1 is a gage height of $3.50 \pm 0.05 \mathrm{ft}$ (L.A. Cottengaim, USGS, station description, unpub. data, 2007), and $3.55 \mathrm{ft}$ is equivalent to a streamflow of $0.34 \mathrm{ft}^{3} / \mathrm{s}$ (U.S. Geological Survey, stage-discharge rating 10.0, November 21, 2006). Therefore, only water-quality samples with an associated streamflow greater than $0.34 \mathrm{ft}^{3} / \mathrm{s}$ were used for site 1 . For sites 2 and 3, only samples with an associated streamflow of at least $4.00 \mathrm{ft}^{3} / \mathrm{s}$ were used. No data were used that were collected after July 13, 2006, for site 2 and July 7, 2006, for site 3 because streamflow was less than $4.0 \mathrm{ft}^{3} / \mathrm{s}$ or was affected by ice for the remainder of 2006. Sites 6 and 7 have higher minimum streamflow caused by regulation at Baldhill Dam and tributary inflow; therefore, data for these sites were not removed based on streamflow.

The frequency of water-quality sampling varied from site to site and with time, resulting in some instances of serial correlation, especially with data collected in the 1980s. To reduce serial correlation, which may result in residuals that are not independent, the data were thinned (Helsel and Hirsch, 1995). After removal of data based on streamflow, the data were thinned for sites $1,4,5,6$, and 7 (fig. 1; table 1) so that no samples were closer than 4 weeks apart. Because of the shorter period of record, data for sites 2 and 3 (fig. 1; table 1) were thinned so that no samples were closer than 3 weeks apart.

\section{Development of Regression Equations to Estimate Constituent Concentrations}

All available water-quality constituents were considered for estimation using regression equations. However, some of them were removed from consideration due to various data issues, such as no data since the early 1980s (bicarbonate), not enough data (total phosphorus), and the data being too coarse, or discrete, for regression analysis (fluoride). Other constituents had enough data, but relations useful for prediction were 
not found (potassium and chloride at sites 1, 4, 5, 6, and 7, and dissolved nitrite plus nitrate at site 1 ). The water-quality constituents selected for estimation are listed in table 2.

The rationale and methodology for expressing waterquality constituent concentrations in terms of other surrogate constituents or physical properties in a regression equation are explained in Helsel and Hirsch (1995). Helsel and Hirsch (1995) also detail the computations for regression estimation and identify measures commonly used to evaluate regression relations, including $R^{2}$, the coefficient of determination. They explain the benefit of log transformation of variables, which was a technique used for some of the regression relations in this study.

$R^{2}$ is calculated as follows:

$$
R^{2}=1-\frac{S S E}{S S_{y}}
$$

where

$$
\begin{gathered}
\text { SSE } \\
\text { is the error sum of squares, and } \\
\text { is the sums of squares y, or total sums of } \\
\text { squares, defined in Helsel and Hirsch } \\
\text { (1995). }
\end{gathered}
$$

$R^{2}$ is a number, 0 through 1 , that when multiplied by 100 is interpreted as the percentage of the variability in the response variable explained by the explanatory variables and the regression equation. Generally, the higher the $R^{2}$, the better the regression relation. However, this does not guarantee the regression equation is useful (Neter and others, 1996). For example, if estimates require extrapolation outside the ranges of observed variables, the regression equation may not provide accurate estimates.

All-subset regression by leaps and bounds, a procedure that attempts to find the best regression relations using subsets of the given explanatory variables (Insightful Corporation, 2005), was used to select the best regression model for estimating a particular constituent. The possible explanatory variables were streamflow, specific conductance, and water temperature (table 3) as well as transformations of streamflow and specific conductance, $\log _{10}$ (streamflow), and $\log _{10}$ (specific conductance) .
The criteria for determining the best regression relation were the adjusted coefficient of multiple determination $\left(R_{a}^{2}\right)$ and Mallow's $C_{p}\left(C_{p}\right) . R^{2}$ increases with the number of explanatory variables in the regression model, but $R_{a}^{2}$ allows for the comparison of models that have differing numbers of explanatory variables by penalizing models that have additional coefficients (Helsel and Hirsch, 1995). The $C_{p}$ criterion is a measure of the total mean squared error and an indicator of model bias (Neter and others, 1996). In comparing models, the models with the lowest $C_{p}$ values are considered those with the least bias.

Potential models with relatively high $R_{a}^{2}$ and low $C_{p}$ were further examined using standard diagnostics for regression (Neter and others, 1996). The most common problems in the diagnostic residual plots were non-normality and heteroscedasticity, or non-constant variance, both violations of the assumptions underlying parametric regression. Transformations of the response variable (constituent concentration in this study) are effective fixes for both of these problems, which often occur together (Neter and others, 1996). Logarithmic transformations of the explanatory and response variables resulted in residuals that were approximately normally distributed. An explanatory variable was considered statistically significant and selected for regression relations if the p-value (attained significance level) for the variable was less than 0.05 .

A resampling technique, jackknife after bootstrap, was used to examine the influence of individual observations in the development of the regression relations. "In bootstrap resampling, $B$ [where $B$ is a large number, such as 1,000] new samples, each of the same size as the observed data, are drawn with replacement from the observed data. The statistic is first calculated using the observed data and then recalculated using each of the new samples, yielding a bootstrap distribution. The resulting replicates are used to calculate the bootstrap estimates of bias, mean, and standard error for the statistic" (Insightful Corporation, 2001a). In this study the bootstrap statistics were the regression parameter estimates, the coefficients of the explanatory variables, and the intercept term. The jackknife after bootstrap was helpful in identifying very influential observations that were removed as outliers and indicated

Table 2. Constituents estimated using regression equations for the Sheyenne River, N. Dak., 1980-2006.

\begin{tabular}{llc}
\hline \multicolumn{1}{c}{ Constituent } & \multicolumn{1}{c}{ Unit of measurement } & $\begin{array}{c}\text { U.S. Geological Survey } \\
\text { parameter code }\end{array}$ \\
\hline Hardness & Milligrams per liter as calcium carbonate & $\mathrm{P} 00900$ \\
Dissolved solids, calculated & Milligrams per liter & $\mathrm{P} 70301$ \\
Calcium & Milligrams per liter & $\mathrm{P} 00915$ \\
Magnesium & Milligrams per liter & $\mathrm{P} 00925$ \\
Sodium & Milligrams per liter & $\mathrm{P} 00930$ \\
Sulfate & Milligrams per liter & $\mathrm{P} 00945$ \\
\hline
\end{tabular}


Table 3. Possible surrogate physical properties, or explanatory variables, used to develop regression relations to estimate constituent concentrations in Sheyenne River, N. Dak., 1980-2006.

\begin{tabular}{llc}
\hline \multicolumn{1}{c}{ Physical properties } & \multicolumn{1}{c}{ Unit of measurement } & $\begin{array}{c}\text { U.S. Geological Survey } \\
\text { parameter code }\end{array}$ \\
\hline Streamflow & Cubic feet per second & P00060 \\
Specific conductance & Microsiemens per centimeter at $25^{\circ}$ Celsius & P00095 \\
Temperature, water & Degrees Celsius & P00010 \\
\hline
\end{tabular}

that the regression parameters estimated in this study were relatively unbiased in their mean and standard error.

An additional measure of influence, Cook's distance, was used along with residual plots to determine outliers or highly influential samples. Cook's distance quantifies the influence of individual samples on the predicted values (Neter and others, 1996).

In building a regression model, the final step of the process is validation of the selected regression model. Validation generally is done in one of three ways: (1) collection of new data to check the model and its predictions; (2) comparison of results with earlier observations, simulations, theoretical experiments, or physical theory; or (3) use of data that were held out of the model-building process to check the model and its prediction accuracy (Neter and others, 1996). Collection of new data is time-consuming and expensive and several years of data may be necessary to obtain samples representative of high and low streamflows, specific conductance, and constituent concentrations. Results of continued water-quality sampling should be compared with the regression relations presented in this report as hydrologic, climatologic, or human factors may change the relations. The regression relations were compared to previous studies and examined for scientific validity. Some data were withheld from the model building process and used to check the predictions made by regression relations.

As an indicator of the ability of the regression relations to estimate constituent concentrations, the measured concentrations were compared to the concentrations estimated by the regression relations by calculating relative percentage differences ( $R P D$ s) using the following equation:

$$
R P D=\left|\frac{E-M}{M} X 100\right|,
$$

where

$$
\begin{gathered}
E \quad \text { is the constituent concentration estimated } \\
\text { from the regression equation, and } \\
M \quad \text { is the measured constituent concentration. }
\end{gathered}
$$

$M$ is assumed to be correct and the $R P D$ is the relative difference of $E$ from $M$, expressed as a percentage.

Logarithmic transformations of the explanatory and response variables resulted in improved RPDs over untransformed variables and in a better linear relation between the measured and estimated concentrations. The improvement in the $R P D$ when the explanatory and response variables were logarithmically transformed is shown in figure 2 for sodium concentrations at site 1 . The top graph shows estimated and measured sodium concentrations with an RPD of 14.3. When the variables were logarithmically transformed, the $R P D$ decreased to 7.5 . In figure $2 A$, the relation between estimated and measured concentrations appears slightly curvilinear, with measured concentrations generally above the estimated concentration line for low concentrations, measured concentrations scattered on both sides of the line for concentrations in the middle, and high measured concentrations below the estimation line. In figure $2 B$ the data generated with logarithmically transformed explanatory and response variables shows a much more linear relation between the measured and estimated concentrations.

Measured and estimated concentrations were compared graphically to evaluate the usefulness of the regression relations for prediction using continuously recorded streamflow and specific conductance data at each gage. The daily mean of the continuously recorded explanatory variables at each site and the regression relations for sulfate were used to predict sulfate concentrations along with 90-percent prediction intervals (Neter and others, 1996). The prediction intervals have a 90-percent probability of containing the true sulfate population (Helsel and Hirsch, 1995).

\section{Calculation of Measured and Estimated Constituent Loads}

Daily load is the total mass of a constituent that is transported past a gaging station in 1 day. Measured constituent loads were calculated by multiplying measured constituent concentrations by streamflow at the time the constituent concentrations were measured and multiplying by the conversion factor listed in table 4. Estimated mean daily constituent loads were calculated by multiplying the daily constituent concentrations estimated using the regression equations by daily streamflow and by a conversion factor (table 4).

For regression relations developed in terms of a logarithmically transformed constituent concentration, retransformation to the original units can cause an underestimation of chemical loads when adding individual load estimates over 


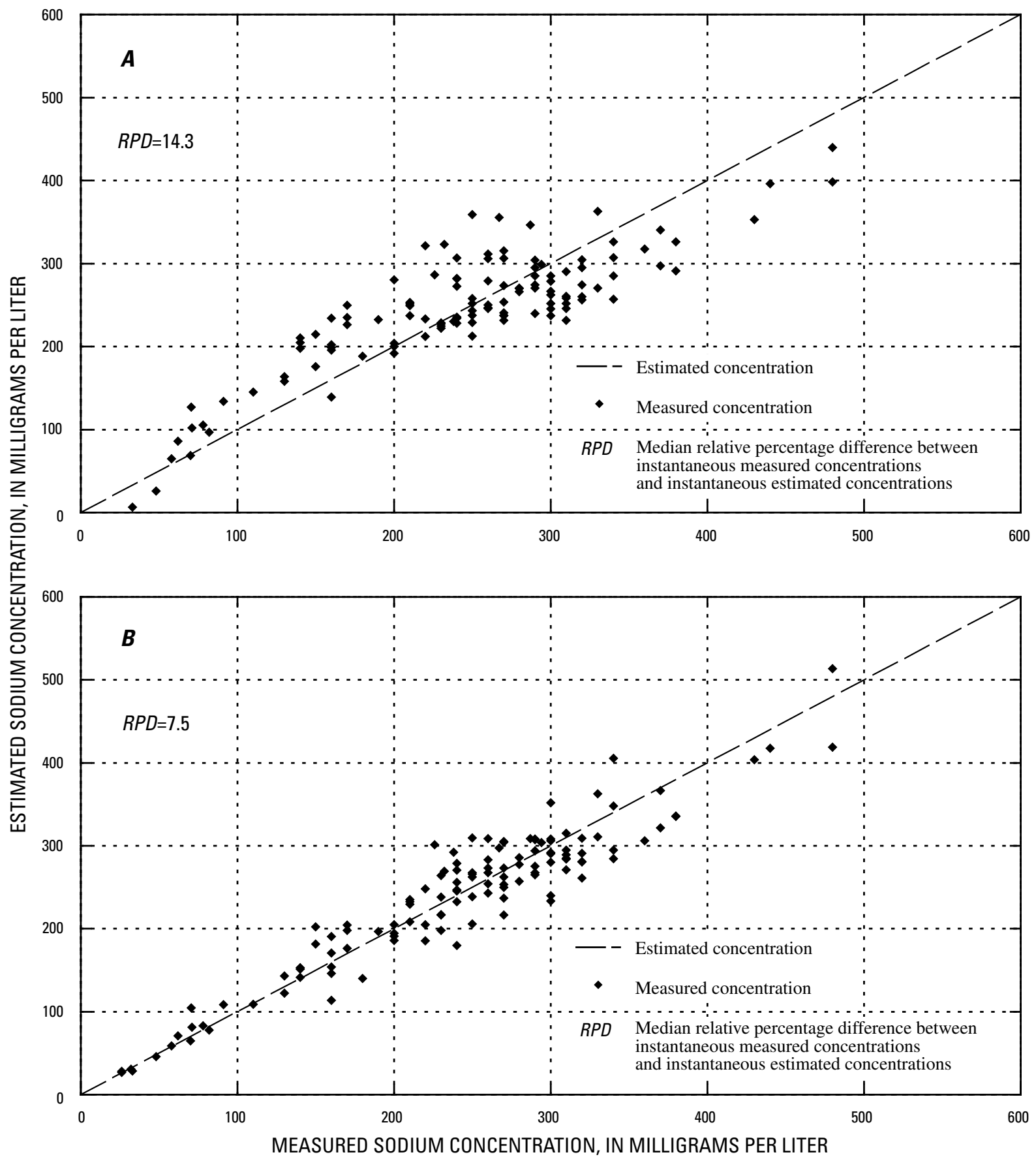

Figure 2. Comparison of measured and estimated sodium concentrations in the Sheyenne River, N. Dak., at site $1, A$ is a comparison using untransformed explanatory and response variables and $B$ is a comparison using logarithmically transformed explanatory and response variables. 
Table 4. Conversion factors used in calculation of measured and estimated loads.

$\left[\mathrm{ft}^{3} / \mathrm{s}\right.$, cubic feet per second]

\begin{tabular}{cccc}
\hline Multiply & By & By & To obtain \\
\hline milligrams per liter & streamflow, in $\mathrm{ft}^{3} / \mathrm{s}$ & 5.39 & pounds per day \\
\hline
\end{tabular}

a long period of time (Christensen, 2001). Multiplying the calculated load by a bias correction factor (BCF; Duan, 1983) corrects for this underestimation. Calculation of the $B C F$ is shown in the equation below:

$$
B C F=\frac{\sum_{i=1}^{n} 10^{e_{i}}}{n}
$$

where

$$
\begin{aligned}
& e_{i} \quad \text { is the regression residual, in log units, and } \\
& n \quad \text { is the number of samples used to develop } \\
& \text { the regression relation. }
\end{aligned}
$$

\section{Continuous Water-Quality Monitoring}

Continuous monitoring of specific conductance and water temperature began at site 1 (fig. 1; table 1) in May 2006 using a Campbell Scientific (CS) 547A conductivity/temperature probe. At site 2 (fig. 1; table 1), continuous monitoring of specific conductance and water temperature began in October 2004 with a CS 547 conductivity/temperature probe. On May 9, 2006, the probe was replaced with a YSI Incorporated (YSI) 600R conductivity/temperature probe. At site 3 (fig. 1; table 1), continuous monitoring of specific conductance and water temperature began in April 2005 with a CS 547 conductivity/temperature probe. On May 8, 2006, the probe was replaced with a YSI 600R conductivity/temperature probe.

At site 4 (fig. 1; table 1), continuous monitoring of specific conductance and water temperature began in May 2006, with a CS 547 conductivity/temperature probe. The probe was installed on the left edge of the water on the same side as a natural spring that discharges to the Sheyenne River 60-70 ft upstream from the probe. Based on field readings on October 24, 2006, the specific conductance in the spring may be lower than the specific conductance in the river and the spring may affect the specific conductance recorded by the probe. A hydrologic comparison of specific conductance at sites 2, 3, 4, and 5 showed that specific conductance at site 4 follows the same trend as that at site 5 but may be influenced by the spring during periods of low streamflow (1-10 $\mathrm{ft}^{3} / \mathrm{s}$ ) (P.M. Scarpari, USGS, station analysis, unpub. data, 2007).
At site 5 (fig. 1; table 1), continuous monitoring of specific conductance and water temperature began in June 1997, with a CS 247 conductivity/temperature probe. At site 6 (fig. 1; table 1), continuous monitoring of specific conductance and water temperature began in April 1997, with a CS 547 conductivity/temperature probe. The probe was initially installed $0.3 \mathrm{mi}$ downstream from the current position. The initial location was downstream from Baldhill Dam and downstream from return flow from the Baldhill Dam National Fish Hatchery. In the new location, since September 18, 2000, only water released from the dam is in contact with the probe (R.A. Nustad, USGS, station description, unpub. data, 2007). At site 7 (fig. 1; table 1), continuous monitoring of specific conductance and water temperature began in June 1997, with a CS 547 conductivity/temperature probe.

The CS probes were installed in buried, flexible polypipe intakes which extended from the gage houses to the river. The pipes were perforated at the end to allow river water to come in contact with the probes. In the CS probes, the electrical conductance sensor "consists of three stainless steel rings mounted in an epoxy tube...Resistance of water passing through the tube is measured by excitation of the center electrode with positive and negative voltage...Temperature is measured with a thermistor in a three wire half bridge configuration" (Campbell Scientific, Inc., 1996, 2000, and 2001). The accuracy of the conductivity sensor in standard ionized solutions is \pm 5 percent of reading in the range of 440 to $7,000 \mu \mathrm{S} / \mathrm{cm}$ at $25^{\circ} \mathrm{C}$ and \pm 10 percent of reading in the range of 5 to $440 \mu \mathrm{S} / \mathrm{cm}$ at $25^{\circ} \mathrm{C}$ (Campbell Scientific, Inc., 1996, 2000 , and 2001). The accuracy of the temperature sensor is $\pm 0.4^{\circ} \mathrm{C}$ in the range of $-24^{\circ} \mathrm{C}$ to $48^{\circ} \mathrm{C}$ (Campbell Scientific, Inc., 1996, 2000, and 2001).

The YSI probes were installed in buried galvanized steel pipe. The pipes were perforated at the end to allow river water to come in contact with the probes. The YSI probes utilize "a cell with four pure nickel electrodes for the measurement of solution conductance. Two of the electrodes are current driven, and two are used to measure the voltage drop" (YSI Incorporated, 2006). For temperature measurement, the probes utilize "a thermistor of sintered metallic oxide that changes predictably in resistance with temperature variation" (YSI Incorporated, 2006). The accuracy of the conductivity sensor is \pm 0.5 percent of reading plus $1 \mu \mathrm{S} / \mathrm{cm}$ in the range of 0 to 
$100,000 \mu \mathrm{S} / \mathrm{cm}$ and the accuracy of the temperature sensor is $\pm 0.15^{\circ} \mathrm{C}$ in the range of -5 to $50^{\circ} \mathrm{C}$ (YSI Incorporated, 2006).

All probes were periodically cleaned and calibrated. For the CS 247, 547, and 547A models, calibration drift corrections were made when the specific conductance readings differed by more than 5 percent of the specific conductance of the standard solution used for calibration. Fouling corrections are made when readings before and after cleaning differed by more than 5 percent (L.A. Cottengaim, USGS, station analysis, unpub. data, 2007). The YSI 600R probes were calibrated and data were corrected according to criteria described by Wagner and others (2000).

The data for all sites were transmitted through satellite telemetry and downloaded into the USGS Automated Data Processing System (ADAPS), and then the data were made available on the Internet from NWISWeb.

\section{Summary Statistics}

Summary statistics of the manually measured physical properties and water-quality constituents are listed in table 5. The data collected by the USGS are stored in the USGS NWIS database and are available online at http://nwis.waterdata. usgs.gov/nd/nwis/qwdata? site_no $=X X X X X X X X$, where

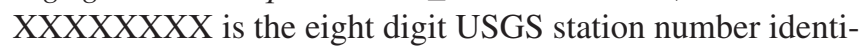
fied in table 1 . The data collected by the NDSWC are stored in the NDSWC's Ground and Surface Water database and are available online at http://www.swc.nd.gov/4dlink2/4dcgi/ wellsearchform/Map\%20and\%20Data\%20Resources.

\section{Results of Regression Analysis}

Regression relations between constituents and surrogate physical properties were examined, and a regression relation was developed for each constituent using one or more surrogate variables. A discussion of each constituent and the associated regression relations follows. Also included in the discussion are the samples, if any, that were removed from the regression analysis. Almost all of the samples removed were from February, March, and November with the majority being from March. These are periods when the sites may be affected by ice, especially sites $1-5$ and 7 ; therefore, caution should be used in using the regression relations for concentration estimation during periods of ice.

\section{Hardness}

Hardness is a property of water resulting from the presence of calcium and magnesium that is associated with the reaction of water with soap (Hem, 1985). The higher the hardness, the more soap is required for cleansing, while water with hardness less than $30-50 \mathrm{mg} / \mathrm{L}$ may be corrosive to pipes, depending on $\mathrm{pH}$, alkalinity, and dissolved oxygen (North Dakota Department of Health, 2006). The hardness data used in this study were expressed in terms of calcium carbonate concentration.

Specific conductance "provides general indication of the content of dissolved matter for water that is not too saline or too dilute" (Hem, 1985); therefore, specific conductance may indicate the presence of calcium and magnesium. Specific conductance was a statistically significant predictor variable for hardness in the Sheyenne River at sites 4, 5, 6, and 7 (table 6). Site 1 showed nonconstant variance in the residual plots and had a high median RPD (greater than 20). Hardness was not analyzed for a regression relation at sites 2 and 3 because of insufficient data.

Regression diagnostics plots, Cook's distance (Neter and others, 1996), and jackknife after bootstrap (Insightful Corporation, 2001b), were all used to examine regression results for outliers and highly influential samples. For site 5, jackknife after bootstrap and Cook's distance indicated that the March 31, 2004, sample was highly influential in the estimation of regression parameters and therefore was removed from the regression analysis. For site 7, jackknife after bootstrap indicated that the February 6, 2006, sample was highly influential in the estimation of regression parameters. This sample also stood out in regression diagnostic plots of the residuals; therefore, the February 6, 2006, sample was removed from the regression analysis.

\section{Dissolved Solids}

Dissolved-solids concentration is used to evaluate water quality and to compare water from one location to the next. Dissolved-solids concentration may be determined in two ways: (1) by the weight of the dry residue remaining after evaporation of the water samples; or (2) by summing the concentrations of other dissolved constituents, if the concentrations of major ions are known (Hem, 1985). According to Hem, the computed value for dissolved solids, which was used in this study, "may give a more useful indication of total dissolved-ion concentration than the residue left by evaporation." High concentrations of dissolved solids may have an adverse effect on taste and make the water appear cloudy (North Dakota Department of Health, 2006).

Specific conductance has been an effective predictor of dissolved solids in previous studies (Ryberg, 2006; and Christensen and others, 2000). Streamflow also may affect dissolved solids, but the relation is not a simple one (Allan, 1995). For the Sheyenne River, specific conductance was a significant explanatory variable for estimating dissolved solids at sites 1, 4, 5, 6, and 7; streamflow was not (table 7). Dissolved solids was not analyzed for a regression relation at sites 2 and 3 because of insufficient data.

Regression diagnostics plots, Cook's distance (Neter and others, 1996), and jackknife after bootstrap (Insightful Corporation, 2001b), were used to examine regression results 
Table 5. Summary of statistics for water-quality sampling sites on the Sheyenne River, N. Dak., 1980-2006.

[Samples for sites 2 and 3 collected by North Dakota State Water Commission, samples for all other sites collected by U.S. Geological Survey; streamflow in cubic feet per second; specific conductance in microsiemens per centimeter at 25 degrees Celsius; temperature in degrees Celsius; hardness in milligrams per liter as calcium carbonate; other constituents in milligrams per liter]

\begin{tabular}{|c|c|c|c|c|c|c|c|c|c|}
\hline \multirow{2}{*}{$\begin{array}{l}\text { Water-quality } \\
\text { physical property } \\
\text { or constituent }\end{array}$} & \multicolumn{4}{|c|}{ Descriptive statistics } & \multicolumn{5}{|c|}{$\begin{array}{l}\text { Percent of samples in which values were less than } \\
\text { or equal to those shown }\end{array}$} \\
\hline & $\begin{array}{l}\text { Sample } \\
\text { size }\end{array}$ & Maximum & Minimum & Mean & 0.95 & 0.75 & $\begin{array}{l}\text { (Median) } \\
0.50\end{array}$ & 0.25 & 0.05 \\
\hline \multicolumn{10}{|c|}{ Site 1, Sheyenne River above Harvey, N. Dak. } \\
\hline Streamflow & 224 & 498 & 0.19 & 36 & 199 & 28 & 6.6 & 2.1 & 0.79 \\
\hline Specific conductance & 215 & 2,300 & 280 & 1,270 & 1,860 & 1,540 & 1,320 & 1,110 & 435 \\
\hline Temperature, water & 221 & 28.2 & 0 & 9.5 & 24.5 & 17.3 & 8.0 & .5 & 0 \\
\hline Hardness & 147 & 550 & 61 & 220 & 440 & 290 & 190 & 140 & 87 \\
\hline $\begin{array}{l}\text { Dissolved solids, } \\
\text { calculated }\end{array}$ & 146 & 1,610 & 192 & 869 & 1,240 & 1,010 & 892 & 793 & 327 \\
\hline Calcium & 146 & 74 & 14 & 36 & 62 & 45 & 34 & 27 & 20 \\
\hline Magnesium & 147 & 92.6 & 5.6 & 30.1 & 65.8 & 42 & 23 & 16 & 8.6 \\
\hline Sodium & 147 & 480 & 20 & 231 & 370 & 300 & 240 & 170 & 57.2 \\
\hline Sulfate & 147 & 610 & 44 & 240 & 460 & 280 & 220 & 180 & 85 \\
\hline Chloride & 146 & 32 & 3.6 & 17 & 28 & 20 & 16 & 13 & 6.0 \\
\hline \multicolumn{10}{|c|}{ Site 2, Sheyenne River above Devils Lake State outlet near Flora, N. Dak. } \\
\hline Streamflow & 125 & 600 & 4.0 & 59 & 264 & 67 & 20 & 8.3 & 4.4 \\
\hline Specific conductance & 125 & 1,880 & 570 & 1,550 & 1,830 & 1,700 & 1,600 & 1,530 & 806 \\
\hline Sulfate & 125 & 520 & 110 & 370 & 490 & 420 & 380 & 330 & 200 \\
\hline \multicolumn{10}{|c|}{ Site 3, Sheyenne River below Devils Lake State outlet near Bremen, N. Dak. } \\
\hline Streamflow & 125 & 579 & 4.0 & 61 & 171 & 84 & 30 & 13 & 5.5 \\
\hline Specific conductance & 125 & 1,880 & 625 & 1,560 & 1,810 & 1,710 & 1,620 & 1,530 & 940 \\
\hline Sulfate & 125 & 540 & 160 & 380 & 500 & 440 & 380 & 350 & 220 \\
\hline \multicolumn{10}{|c|}{ Site 4, Sheyenne River near Warwick, N. Dak. } \\
\hline Streamflow & 247 & 3,160 & 0.29 & 206 & 997 & 156 & 29 & 11 & 2.2 \\
\hline Specific conductance & 238 & 1,900 & 218 & 903 & 1,420 & 1,130 & 909 & 655 & 440 \\
\hline Temperature, water & 243 & 30.0 & 0 & 9.9 & 25.9 & 18.0 & 8.0 & 1.0 & 0 \\
\hline Hardness & 60 & 430 & 87 & 260 & 380 & 320 & 270 & 190 & 100 \\
\hline $\begin{array}{l}\text { Dissolved solids, } \\
\text { calculated }\end{array}$ & 60 & 911 & 184 & 530 & 851 & 713 & 527 & 363 & 223 \\
\hline Calcium & 60 & 79 & 20 & 48 & 68 & 56 & 49 & 38 & 23 \\
\hline Magnesium & 60 & 59 & 9.0 & 33 & 52 & 43 & 33 & 22 & 12 \\
\hline Sodium & 60 & 190 & 14 & 92 & 160 & 130 & 81 & 51 & 25 \\
\hline Sulfate & 60 & 310 & 37 & 140 & 280 & 210 & 130 & 80.5 & 46.8 \\
\hline Chloride & 60 & 37 & 3.5 & 14 & 22 & 17 & 14 & 10 & 5.5 \\
\hline
\end{tabular}


Table 5. Summary of statistics for water-quality sampling sites on the Sheyenne River, N. Dak., 1980-2006. - Continued

[Samples for sites 2 and 3 collected by North Dakota State Water Commission, samples for all other sites collected by U.S. Geological Survey; streamflow in cubic feet per second; specific conductance in microsiemens per centimeter at 25 degrees Celsius; temperature in degrees Celsius; hardness in millligrams per liter as calcium carbonate; other constituents in milligrams per liter]

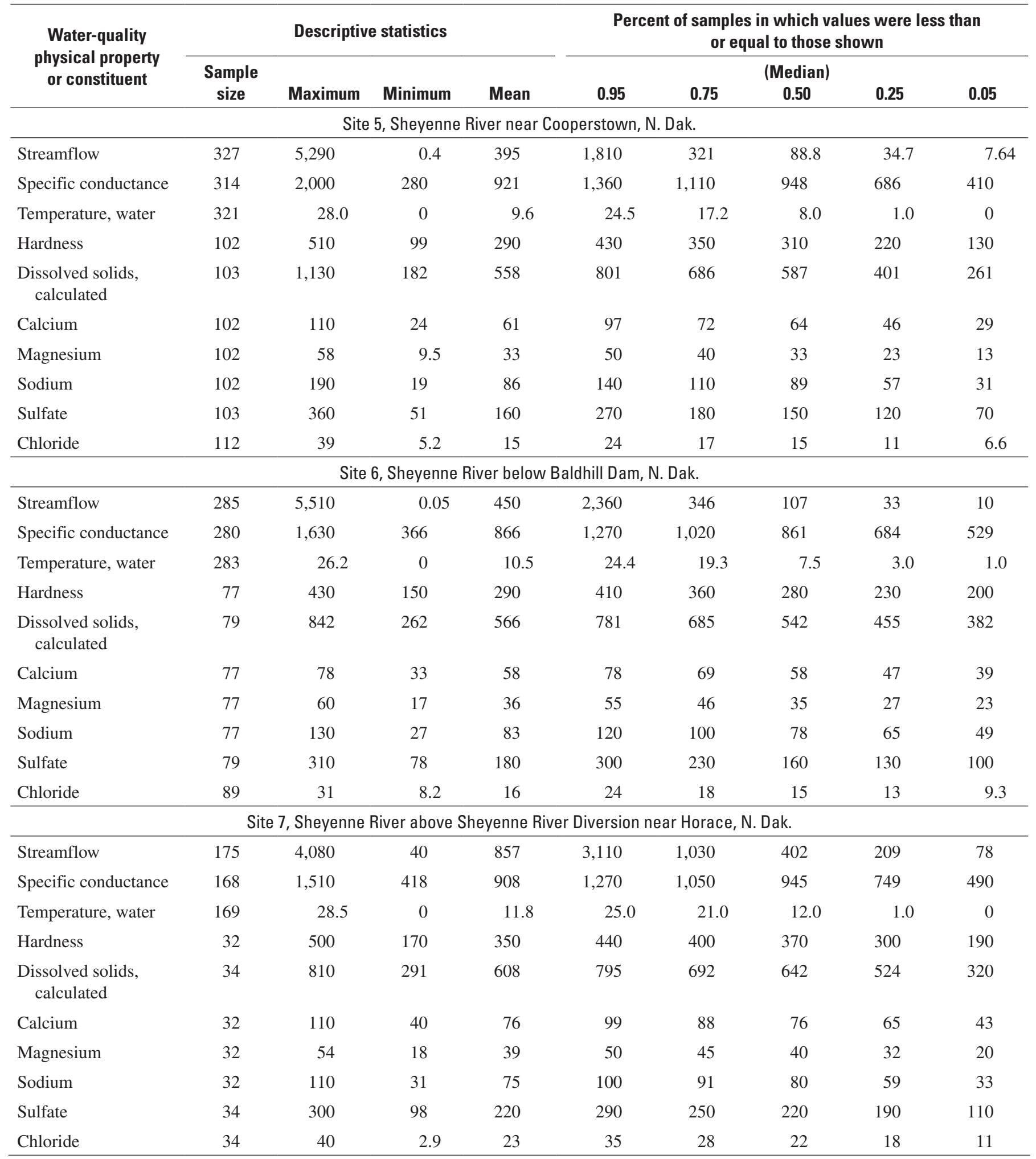


for outliers or highly influential points. For site 5, the sample from March 28, 1991, appeared to be an outlier in regression diagnostic plots and the sample from March 31, 2004, was highly influential in the estimation of regression parameters based on Cook's distance and jackknife after bootstrap; both samples were removed. For site 6, the sample from November 21, 2005, appeared to be an outlier in residual plots and had a large Cook's distance; therefore, the sample was removed from the regression analysis.

Table 6. Regression equations for estimates of hardness in the Sheyenne River, N. Dak., 1980-2006.

[n, numbers of samples used to develop regression equation; $\mathrm{CaCO}_{3}$, hardness, in milligrams per liter as calcium carbonate; $\mathrm{SC}$, specific conductance, in microsiemens per centimeter at 25 degrees Celsius; $R^{2}$, coefficient of multiple determination; median $R P D$, median relative percentage difference; $B C F$, bias correction factor; --, not applicable]

\begin{tabular}{|c|c|c|c|c|c|c|}
\hline $\begin{array}{c}\text { Site } \\
\text { number }\end{array}$ & $n$ & Equation & $\begin{array}{c}\text { Range of } \\
\text { explanatory } \\
\text { variable }\end{array}$ & $R^{2}$ & $\begin{array}{c}\text { Median } \\
\text { RPD }\end{array}$ & $B C F$ \\
\hline 1 & -- & -- & -- & -- & -- & -- \\
\hline 2 & -- & -- & -- & -- & -- & -- \\
\hline 3 & -- & -- & -- & -- & -- & -- \\
\hline 4 & 45 & $\log _{10}\left(\mathrm{CaCO}_{3}\right)=0.991 \log _{10}(S C)-0.501$ & $S C: 311-1,372$ & 0.915 & 7.7 & 1.0081 \\
\hline 5 & 64 & $\log _{10}\left(\mathrm{CaCO}_{3}\right)=1.040 \log _{10}(S C)-0.601$ & $S C: 295-1,600$ & .947 & 6.1 & 1.0041 \\
\hline 6 & 65 & $\log _{10}\left(\mathrm{CaCO}_{3}\right)=1.003 \log _{10}(S C)-0.489$ & $S C: 438-1,320$ & .936 & 3.9 & 1.0020 \\
\hline 7 & 30 & $\log _{10}\left(C a C O_{3}\right)=1.016 \log _{10}(S C)-0.482$ & $S C: 449-1,293$ & .942 & 5.8 & 1.0020 \\
\hline
\end{tabular}

Table 7. Regression equations for estimates of dissolved solids in the Sheyenne River, N. Dak., 1980-2006.

[n, numbers of samples used to develop regression equation; $D S$, dissolved solids concentration, in milligrams per liter; $S C$, specific conductance, in microsiemens per centimeter at 25 degrees Celsius; $R^{2}$, coefficient of multiple determination; median $R P D$, median relative percentage difference; $B C F$, bias correction factor; --, not applicable]

\begin{tabular}{|c|c|c|c|c|c|c|}
\hline $\begin{array}{c}\text { Site } \\
\text { number }\end{array}$ & n & Equation & $\begin{array}{l}\text { Range of } \\
\text { explanatory } \\
\text { variable }\end{array}$ & $R^{2}$ & $\begin{array}{c}\text { Median } \\
\text { RPD }\end{array}$ & $B C F$ \\
\hline 1 & 127 & $\log _{10}(D S)=1.054 \log _{10}(S C)-0.352$ & $S C: 320-2,300$ & 0.986 & 2.2 & 1.0011 \\
\hline 2 & -- & -- & -- & -- & -- & -- \\
\hline 3 & -- & -- & -- & -- & -- & -- \\
\hline 4 & 45 & $\log _{10}(D S)=1.098 \log _{10}(S C)-0.488$ & $S C: 311-1,372$ & .993 & 1.7 & 1.0008 \\
\hline 5 & 64 & $\log _{10}(D S)=1.065 \log _{10}(S C)-0.386$ & $S C: 320-2,300$ & .991 & 2.2 & 1.0007 \\
\hline 6 & 65 & $\log _{10}(D S)=1.046 \log _{10}(S C)-0.328$ & $S C: 295-1,600$ & .997 & 2.6 & 1.0007 \\
\hline 7 & 30 & $\log _{10}(D S)=1.032 \log _{10}(S C)-0.290$ & $S C: 449-1,380$ & .966 & 2.7 & 1.0012 \\
\hline
\end{tabular}




\section{Calcium}

Calcium contributes to hardness, is "a major component of the solutes in most natural waters," and it is generally "the predominant cation in river water" (Hem, 1985). Previous studies have shown a positive linear relation between calcium and specific conductance (Christensen and others, 2003; Rasmussen and others, 2005; Christensen and others, 2006). Specific conductance was a statistically significant predictor variable for calcium in the Sheyenne River at sites 4, 5, 6, and 7 (table 8). Streamflow was also a statistically significant predictor variable for calcium in the Sheyenne River at sites 5, 6, and 7. Despite logarithmic transformation of the explanatory and response variables, site 1 had a nonlinear regression relation; therefore, a relation is not reported for calcium at site 1 . This supports the lack of relation found for hardness as well. Calcium was not analyzed for a regression relation at sites 2 and 3 because of insufficient data.

\section{Magnesium}

Magnesium contributes to hardness and is "a common element essential in plant and animal nutrition" (Hem, 1985). Previous studies have shown a positive linear relation between magnesium and specific conductance (Rasmussen and others, 2004; Christensen and others, 2006). Specific conductance was a statistically significant predictor variable for magnesium in the Sheyenne River at sites 4, 5, 6, and 7 (table 9). Streamflow was also a statistically significant predictor variable for magnesium in the Sheyenne River at site 5. Despite logarithmic transformation of the explanatory and response variables, site 1 showed nonconstant variance in the residuals; therefore a relation is not reported for magnesium at site 1. This supports the lack of relation found for hardness as well. Magnesium was not analyzed for a regression relation at sites 2 and 3 because of insufficient data.

\section{Sodium}

Sodium in drinking water may be a concern for individuals on sodium restricted diets and high concentrations of sodium may make water unsuitable for irrigation (North Dakota Department of Health, 2006). Human activities, such as deicing of highways in the winter, may influence the concentrations of sodium in ground and surface water (Hem, 1985).

Previous studies have shown a positive linear relation between sodium and specific conductance, as well as multiple regression relations that include $\mathrm{pH}$ and streamflow in addition to specific conductance (Christensen and others 2003; Rasmussen and others, 2004; Christensen and others, 2006). Specific conductance was a statistically significant predictor variable for sodium in the Sheyenne River at sites 1, 4, 5, 6, and 7 (table 10). Streamflow was also a statistically significant predictor variable for sodium in the Sheyenne River at sites 1 and 6 . Sodium was not analyzed for a regression relation at sites 2 and 3 because of insufficient data.

Table 8. Regression equations for estimates of calcium in the Sheyenne River, N. Dak., 1980-2006.

[n, numbers of samples used to develop regression equation; $C a$, calcium concentration, in milligrams per liter; $Q$, streamflow, in cubic feet per second; $S C$, specific conductance, in microsiemens per centimeter at 25 degrees Celsius; $R^{2}$, coefficient of multiple determination; median $R P D$, median relative percentage difference; $B C F$, bias correction factor; --, not applicable]

\begin{tabular}{|c|c|c|c|c|c|c|}
\hline $\begin{array}{c}\text { Site } \\
\text { number }\end{array}$ & $\mathbf{n}$ & Equation & $\begin{array}{l}\text { Range of } \\
\text { explanatory } \\
\text { variable(s) }\end{array}$ & $R^{2}$ & $\begin{array}{l}\text { Median } \\
\text { RPD }\end{array}$ & $B C F$ \\
\hline 1 & -- & -- & -- & -- & -- & -- \\
\hline 2 & -- & -- & -- & -- & -- & -- \\
\hline 3 & -- & -- & -- & -- & -- & -- \\
\hline 4 & 45 & $\log _{10}(C a)=0.770 \log _{10}(S C)-0.585$ & $S C: 311-1,372$ & 0.784 & 9.5 & 1.0148 \\
\hline 5 & 65 & $\begin{array}{l}\log _{10}(C a)=-0.040 \log _{10}(Q)+0.818 \log _{10}(S C) \\
-0.548\end{array}$ & $\begin{array}{l}Q: 7.6-4,260 \\
S C: 280-1,600\end{array}$ & .909 & 7.6 & 1.0065 \\
\hline 6 & 65 & $\begin{array}{l}\log _{10}(C a)=0.014 \log _{10}(Q)+0.856 \log _{10}(S C) \\
-0.790\end{array}$ & $\begin{array}{l}Q: 8.2-3,050 \\
S C: 438-1,362\end{array}$ & .839 & 5.7 & 1.0040 \\
\hline 7 & 27 & $\begin{array}{l}\log _{10}(C a)=-0.061 \log _{10}(Q)+0.708 \log _{10}(S C) \\
-0.080\end{array}$ & $\begin{array}{l}Q: 60.2-3,810 \\
S C: 449-1,380\end{array}$ & .884 & 5.3 & 1.0037 \\
\hline
\end{tabular}


Table 9. Regression equations for estimates of magnesium in the Sheyenne River, N. Dak., 1980-2006.

[n, numbers of samples used to develop regression equation; $M g$, magnesium concentration, in milligrams per liter; $Q$, streamflow, in cubic feet per second; $S C$, specific conductance, in microsiemens per centimeter at 25 degrees Celsius; $R^{2}$, coefficient of multiple determination; median $R P D$, median relative percentage difference; $B C F$, bias correction factor; --, not applicable]

\begin{tabular}{|c|c|c|c|c|c|c|}
\hline $\begin{array}{c}\text { Site } \\
\text { number }\end{array}$ & $n$ & Equation & $\begin{array}{l}\text { Range of } \\
\text { explanatory } \\
\text { variable(s) }\end{array}$ & $R^{2}$ & $\begin{array}{c}\text { Median } \\
\text { RPD }\end{array}$ & $B C F$ \\
\hline 1 & -- & -- & -- & -- & -- & -- \\
\hline 2 & -- & -- & -- & -- & -- & -- \\
\hline 3 & -- & -- & -- & -- & -- & -- \\
\hline 4 & 45 & $\log _{10}(M g)=1.205 \log _{10}(S C)-2.016$ & $S C: 311-1,372$ & 0.953 & 6.6 & 1.0062 \\
\hline 5 & 65 & $\begin{array}{l}\log _{10}(M g)=0.038 \log _{10}(Q)+1.232 \log _{10}(S C) \\
-2.181\end{array}$ & $\begin{array}{l}Q: 7.6-4,260 \\
S C: 280-1,600\end{array}$ & .949 & 6.8 & 1.0054 \\
\hline 6 & 65 & $\log _{10}(M g)=1.144 \log _{10}(S C)-1.814$ & $S C: 438-1,320$ & .944 & 4.9 & 1.0023 \\
\hline 7 & 28 & $\log _{10}(M g)=1.079 \log _{10}(S C)-1.627$ & $S C: 449-1,380$ & .955 & 4.9 & 1.0018 \\
\hline
\end{tabular}

\section{Sulfate}

Sulfate sources include the weathering of rocks, agricultural runoff, fuel combustion, municipal and industrial effluent, and precipitation (Hem, 1985; Allan, 1995). The presence of too much sulfate has three main undesirable effects in water used by humans: (1) sulfate can have a laxative effect with excessive intake, (2) water with high sulfate concentrations can form hard scales in boilers, and (3) sulfate can negatively affect taste (North Dakota Department of Health, 2006). Sulfate is negatively charged and increased sulfate concentrations increase specific conductance (Hem, 1985). Streamflow was statistically significant at sites 1,4 , and 5 only (table 11).

Jackknife after bootstrap, Cook's distance, and regression plots identified the March 30, 2005, sample at site 1, the November 21, 2005, sample at site 6, and the September 16, 1993, sample at site 7 as highly influential points. They were removed from the regression analyses.

For sites 2 and 3, the period of record is small compared to the other sites and it is a period of record with relatively low flow and high specific conductance. Additional high flow data might result in the inclusion of the streamflow term in the regression equation, which is present in the equations for the upstream and downstream sites (1 and 4). The equations presented in table 11 should not be extrapolated beyond the range of explanatory variables used to develop the regression equations.

Additional high flow data might include concentrations affected by storm runoff and sites 1, 2, and 3 may be more affected by storm runoff than sites farther downstream. The storm effect would depend on the location of the storm. The north fork of the Sheyenne River, which joins the Sheyenne
River between Harvey and Flora (fig. 1) is less sulfatic than the Sheyenne River (W.M. Schuh, North Dakota State Water Commission, written commun., 2007). Therefore, increased streamflow at sites 2 and 3 caused by storm runoff may have varying effects on sulfate because of the location of the storm.

In addition to the numeric measurements used to evaluate the regression relations, measured and estimated concentrations were compared graphically to evaluate the usefulness of the regression relations for prediction using continuously recorded streamflow and specific conductance data at each gage. The permit to release water from the Devils Lake outlet into the Sheyenne River is based in part on sulfate concentration; therefore, there is a great deal of interest in sulfate in the Sheyenne River Basin and sulfate was used to illustrate the graphical comparison of measured and estimated concentrations in figures 3 and 4 . For sites 1 and 4, continuous recording of specific conductance began in May 2006, resulting in little data for continuous prediction in 2006; therefore, sites 1 and 4 are not compared graphically. For sites 2 and 3, the daily mean of the continuously recorded specific conductance and streamflow data at each site from January 1, 2005, through December 31, 2006, and the regression relations for sulfate were used to predict sulfate concentrations along with 90-percent prediction intervals, representing the error in the prediction of sulfate. The sample concentrations used to develop the regression relations were plotted as points as well as the sample concentrations that were removed when the data were thinned. The regression relations for sites 2 and 3 were developed using samples collected by the NDSWC; however, the USGS also collected samples at these sites as an independent verification of the NDSWC's sampling program and the USGS sample concentrations also are plotted as points. 
Table 10. Regression equations for estimates of sodium in the Sheyenne River, N. Dak., 1980-2006.

[n, numbers of samples used to develop regression equation; $N a$, sodium concentration, in milligrams per liter; $Q$, streamflow, in cubic feet per second; $S C$, specific conductance, in microsiemens per centimeter at 25 degrees Celsius; $R^{2}$, coefficient of multiple determination; median $R P D$, median relative percentage difference; $B C F$, bias correction factor; --, not applicable]

\begin{tabular}{|c|c|c|c|c|c|c|}
\hline $\begin{array}{c}\text { Site } \\
\text { number }\end{array}$ & $\mathbf{n}$ & Equation & $\begin{array}{l}\text { Range of } \\
\text { explanatory } \\
\text { variable(s) }\end{array}$ & $R^{2}$ & $\begin{array}{c}\text { Median } \\
\text { RPD }\end{array}$ & $B C F$ \\
\hline 1 & 125 & $\begin{array}{l}\log _{10}(N a)=-0.120 \log _{10}(Q)+1.168 \log _{10}(S C) \\
-1.217\end{array}$ & $\begin{array}{l}Q: 0.35-362 \\
S C: 320-2,300\end{array}$ & 0.952 & 7.5 & 1.0076 \\
\hline 2 & -- & -- & -- & -- & -- & -- \\
\hline 3 & -- & -- & -- & -- & -- & -- \\
\hline 4 & 43 & $\log _{10}(N a)=1.379 \log _{10}(S C)-2.069$ & $S C: 311-1,372$ & .958 & 9.2 & 1.0072 \\
\hline 5 & 65 & $\log _{10}(N a)=1.282 \log _{10}(S C)-1.857$ & $S C: 280-1,600$ & .938 & 9.0 & 1.0083 \\
\hline 6 & 64 & $\begin{array}{l}\log _{10}(N a)=-0.029 \log _{10}(Q)+1.235 \log _{10}(S C) \\
-1.671\end{array}$ & $\begin{array}{l}Q: 8.2-3,050 \\
S C: 438-1,362\end{array}$ & .886 & 7.5 & 1.0058 \\
\hline 7 & 28 & $\log _{10}(N a)=1.242 \log _{10}(S C)-1.827$ & $S C: 449-1,380$ & .876 & 8.8 & 1.0075 \\
\hline
\end{tabular}

Table 11. Regression equations for estimates of sulfate in the Sheyenne River, N. Dak., 1980-2006.

[n, numbers of samples used to develop regression equation; $S O_{4}$, sulfate concentration, in milligrams per liter; $Q$, streamflow. in cubic feet per second; $S C$, specific conductance, in microsiemens per centimeter at 25 degrees Celsius; $R^{2}$, coefficient of multiple determination; median $R P D$, median relative percentage difference; $B C F$, bias correction factor; --, not applicable]

\begin{tabular}{|c|c|c|c|c|c|c|}
\hline $\begin{array}{c}\text { Site } \\
\text { number }\end{array}$ & n & Equation & $\begin{array}{l}\text { Range of } \\
\text { explanatory } \\
\text { variable(s) }\end{array}$ & $R^{2}$ & Median RPD & $B C F$ \\
\hline 1 & 125 & $\begin{array}{l}\log _{10}\left(S O_{4}\right)=0.161 \log _{10}(Q)+1.492 \log _{10}(S C) \\
-2.414\end{array}$ & $\begin{array}{l}Q: 0.35-362 \\
S C: 320-2,300\end{array}$ & 0.894 & 8.0 & 1.0108 \\
\hline 2 & 11 & $\log _{10}\left(S O_{4}\right)=1.251 \log _{10}(S C)-1.434$ & $S C: 575-1,760$ & .922 & 8.9 & 1.0059 \\
\hline 3 & 11 & $\log _{10}\left(S O_{4}\right)=1.021 \log _{10}(S C)-0.692$ & $S C: 625-1,812$ & .850 & 8.2 & 1.0072 \\
\hline 4 & 45 & $\begin{array}{l}\log _{10}\left(S O_{4}\right)=0.126 \log _{10}(Q)+1.475 \log _{10}(S C) \\
-2.420\end{array}$ & $\begin{array}{l}Q: 9-2,120 \\
S C: 311-1,372\end{array}$ & .898 & 7.9 & 1.0145 \\
\hline 5 & 66 & $\begin{array}{l}\log _{10}\left(S O_{4}\right)=0.096 \log _{10}(Q)+1.308 \log _{10}(S C) \\
-1.848\end{array}$ & $\begin{array}{l}Q: 7.6-4,260 \\
S C: 280-1,600\end{array}$ & .893 & 9.8 & 1.0108 \\
\hline 6 & 65 & $\log _{10}\left(S O_{4}\right)=1.318 \log _{10}(S C)-1.635$ & $S C: 438-1,362$ & .820 & 11.5 & 1.0107 \\
\hline 7 & 28 & $\log _{10}\left(S O_{4}\right)=1.026 \log _{10}(S C)-0.722$ & $S C: 449-1,380$ & .928 & 5.2 & 1.0026 \\
\hline
\end{tabular}



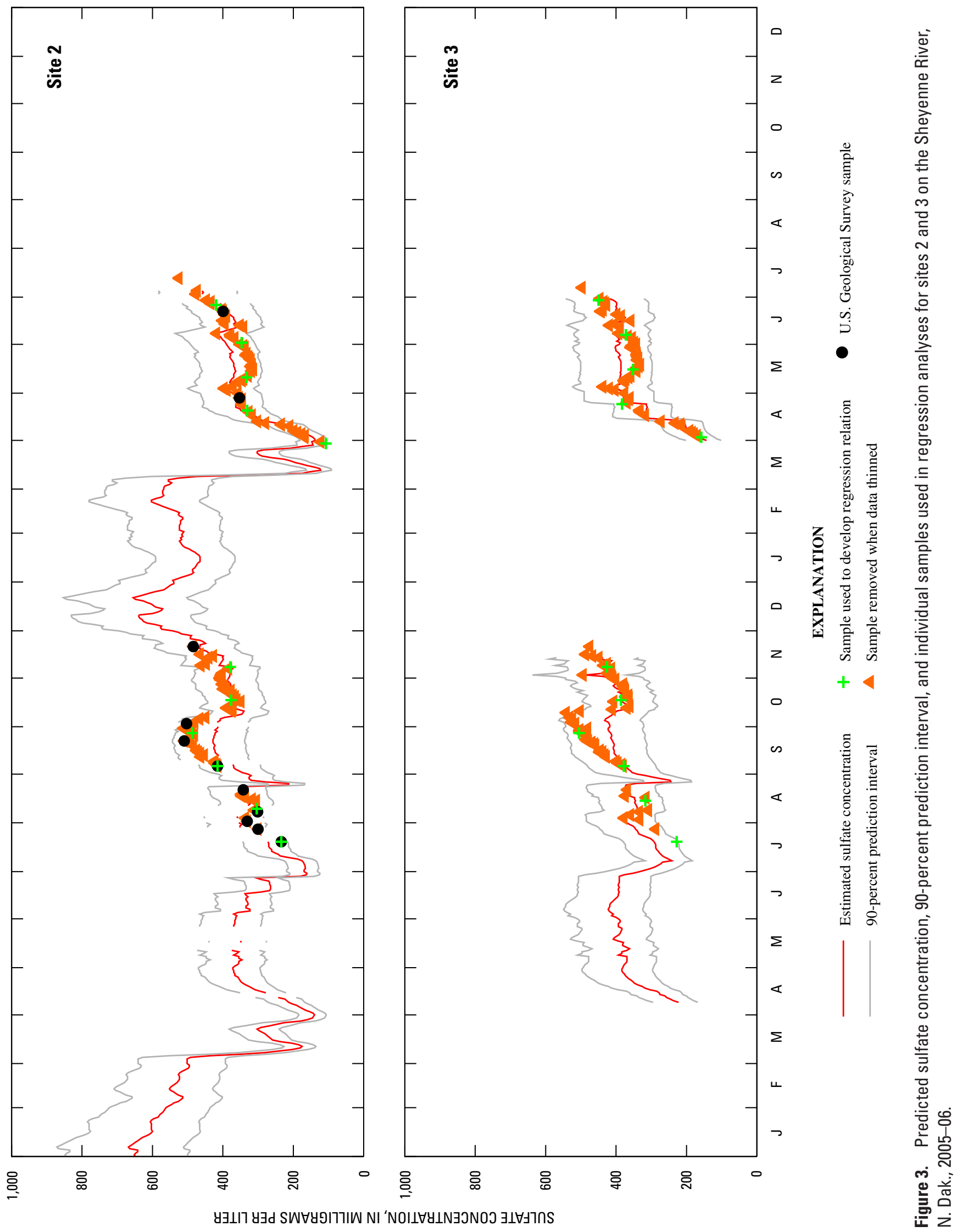

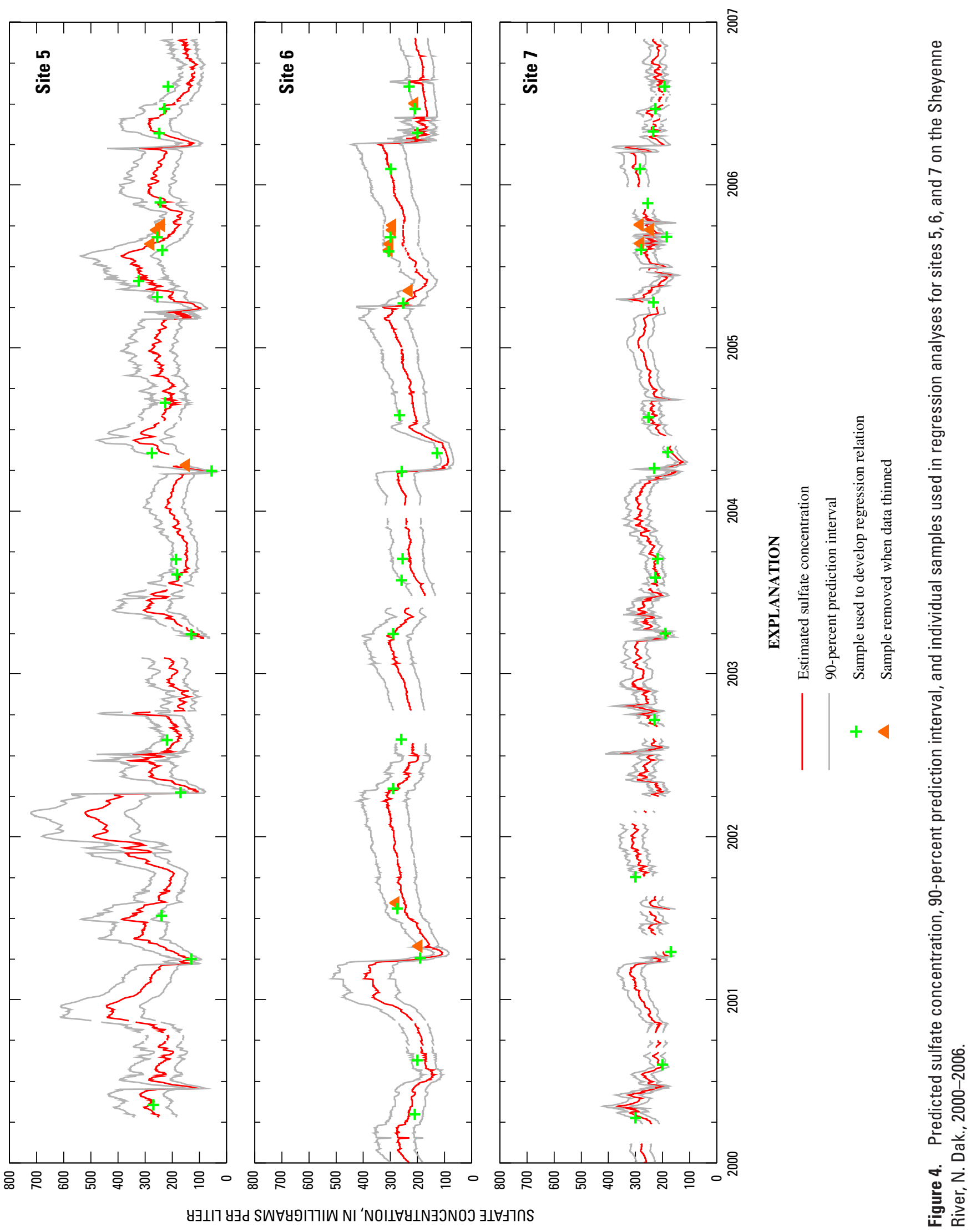
For sites 5, 6, and 7, the daily mean of the continuously recorded specific conductance and streamflow data from January 1, 2000, through December 31, 2006, and the regression relations for sulfate were used to predict sulfate concentrations at each site along with 90-percent prediction intervals, representing the error in the prediction of sulfate. The sample concentrations used to develop the regression relations were plotted as points, as well as the sample concentrations that were removed when the data were thinned. Breaks in the prediction lines (figs. 3 and 4) indicate periods in which one or more of the predictor variables were unavailable or periods in which streamflow fell outside the bounds defined in the "Manual Water-Quality Measurements, Sample Collection, and Analysis" section of this report.

\section{Measured and Estimated Constituent Loads}

Because the explanatory variables used in the regression equations (tables 6-11) are continuously monitored properties, the regression relations developed in this study may be used to estimate daily constituent loads in the Sheyenne River. As an example of this application of the relations, the daily load for sulfate at site 7 is shown in figure 5. Measured daily load was computed and the daily load was estimated using the regression equation (table 11) and the daily mean streamflow and specific conductance. Breaks in the line representing estimated daily load indicate periods in which one or more of the explanatory variables was unavailable.

The estimated loads and measured loads compare well and the estimated load illustrates the high degree of variability in daily sulfate load. The peak load generally occurs in the second quarter of the year during spring runoff, April-June.

\section{Summary}

The U.S. Geological Survey, in cooperation with the North Dakota State Water Commission (NDSWC), analyzed data collected at seven sites on the Sheyenne River to determine whether streamflow and the continuously recorded physical properties could act as surrogates to estimate waterquality constituents that are important indicators of surfacewater quality. Estimation of water-quality constituents on

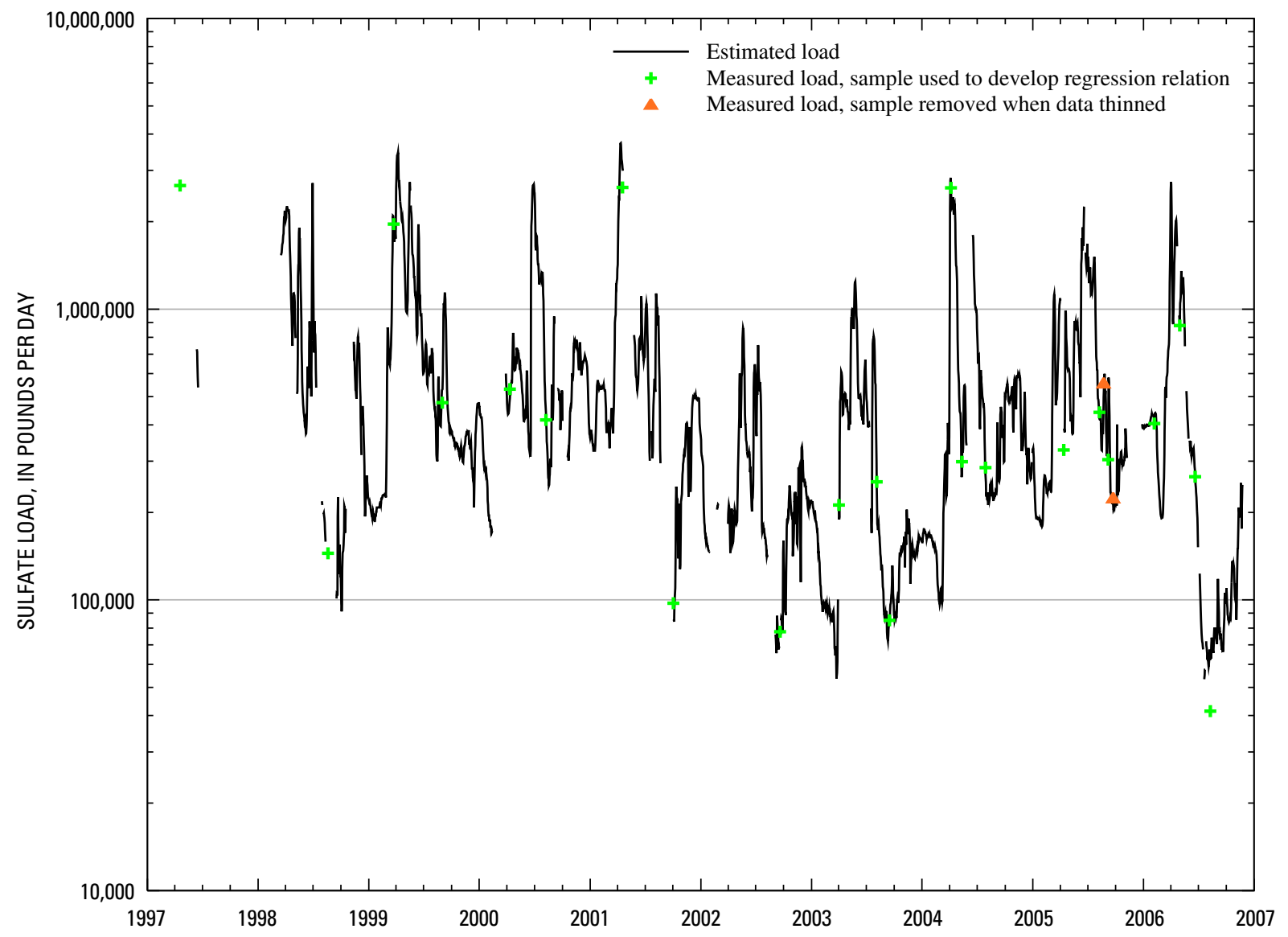

Figure 5. Comparison of measured and estimated sulfate loads for site 7 on the Sheyenne River, N. Dak., $1997-2006$. 
the basis of surrogates provides several benefits. Although periodic Sheyenne River water-quality samples are collected manually and analyzed, the delay associated with laboratory analysis does not permit immediate identification of undesirable concentrations of constituents. A relation between manually collected water-quality samples and real-time water-quality measurements allows immediate identification of potential water-quality problems. Examination of streamflow and physical properties of water that act as surrogates for constituents of interest also helps optimize visits for the collection of water-quality samples.

Data collection and analysis methods, as well as the periods of record for manual and continuous water-quality monitoring, vary among the sites. This variability was documented as part of the study and should be considered when applying the regression relations.

Constituents for which regression relations were developed were hardness, dissolved solids, calcium, magnesium, sodium, and sulfate. Potential explanatory variables were the continuously recorded water properties streamflow, specific conductance, and water temperature. Each regression relation was evaluated for usefulness based on the $R^{2}$ and median relative percentage differences $(R P D \mathrm{~s})$.

The base-10 logarithm of hardness was a function of the base-10 logarithm of specific conductance for sites 4-7. The hardness relations were characterized by $R^{2}$ of $0.915-0.947$ and median RPDs of 3.9-7.7.

The base-10 logarithm of dissolved solids was a function of the base-10 logarithm of specific conductance for sites 1 and 4-7. The dissolved solids relations were characterized by $R^{2}$ of 0.966-0.997 and median RPDs of 1.7-2.7.

The base-10 logarithm of calcium was a function of the base-10 logarithm of specific conductance for site 4 and a function of the base-10 logarithm of streamflow and the base-10 logarithm of specific conductance for sites 5-7. The calcium relations were characterized by $R^{2}$ of $0.784-0.909$ and median RPDs of 5.3-9.5.

The base-10 logarithm of magnesium was a function of the base-10 logarithm of specific conductance for sites 4,6 , and 7 and a function of the base-10 logarithm of streamflow and the base-10 logarithm specific conductance for site 5 . The magnesium relations were characterized by $R^{2}$ of $0.944-0.955$ and median RPDs of 4.9-6.8.

The base-10 logarithm of sodium was a function of the base-10 logarithm of streamflow and the base-10 logarithm of specific conductance for sites 1 and 6 and a function of the base-10 logarithm of specific conductance for sites 4, 5, and 7 . The sodium relations were characterized by $R^{2}$ of $0.876-0.958$ and median RPDs of 7.5-9.2.

The base-10 logarithm of sulfate was a function of the base-10 logarithm of streamflow and the base- 10 logarithm of specific conductance for sites 1,4 , and 5 and a function of the base-10 logarithm of specific conductance for sites 2 , 3,6 , and 7 . The sulfate relations were characterized by $R^{2}$ of 0.820-0.928 and median RPDs of 5.2-11.5.
The regression relations may be used to continuously estimate constituent concentrations in the Sheyenne River and these estimates may be used to continuously estimate concentration loads. The relations should be monitored for change over time, especially at sites 2 and 3 which have a short period of record. In addition, caution should be used when the Sheyenne River is affected by ice and when the upstream sites (sites 1,2, and 3) are affected by isolated storm runoff. Almost all of the outliers and highly influential samples removed from the analysis were from periods when the Sheyenne River might be affected by ice.

\section{References Cited}

Allan, J.D., 1995, Stream ecology-Structure and function of running waters: London, Chapman \& Hall, 388 p.

Buchanan, T.J., and Somers, W.P., 1969, Discharge measurements at gaging stations: U.S. Geological Survey Techniques of Water-Resources Investigations, book 3, chap. A8, 65 p., accessed June 2, 2006, at http://pubs.usgs.gov/twri/ twri3a8/

Campbell Scientific, Inc., 1996, 247 conductivity \& temperature probes; Logan, Utah, Campbell Scientific, Inc., 11 p., accessed April 9, 2007, at http://www.campbellsci.com/ documents/manuals/retired/247.pdf

Campbell Scientific, Inc., 2000, CS547 Conductivity and temperature probe and A547 interface; Logan, Utah, Campbell Scientific, Inc., 20 p., accessed April 9, 2007, at http://www. campbellsci.com/documents/manuals/cs547.pdf

Campbell Scientific, Inc., 2001, CS547A Conductivity and temperature probe and A547 interface; Logan, Utah, Campbell Scientific, Inc., 20 p., accessed April 9, 2007, at http://www.campbellsci.com/documents/manuals/cs547a.pdf

Christensen, V.G., 2001, Characterization of surface-water quality based on real-time monitoring and regression analysis, Quivira National Wildlife Refuge, south-central Kansas, December 1998 through June 2001: U.S. Geological Survey Water-Resources Investigations Report 01-4248, 28 p., accessed March 2, 2006, at http://pubs.water.usgs. gov/wri014248

Christensen, V.G., Graham, J.L., Milligan, C.R., Pope, L.M., and Ziegler, A.C., 2006, Water quality and relation to tasteand-odor compounds in the North Fork Ninnescah River and Cheney Reservoir, south-central Kansas, 1997-2003: U.S. Geological Survey Scientific Investigations Report 2006-5095, 43 p., accessed April 24, 2007, at http://pubs. usgs.gov/sir/2006/5095/ 
Christensen, V.G., Jian, Xiaodong, and Ziegler, A.C., 2000, Regression analysis and real-time water-quality monitoring to estimate constituent concentrations, loads, and yields in the Little Arkansas River, south-central Kansas, 1995-99: U.S. Geological Survey Water-Resources Investigations Report 00-4126, 36 p., accessed March 2, 2006, at http:// pubs.water.usgs.gov/wri004126

Christensen, V.G., Ziegler, A.C., Rasmussen, P.P., and Jian, Xiaodong, 2003, Continuous real-time water-quality monitoring of Kansas streams, in Proceedings of 2003 Spring Specialty Conference on Agricultural Hydrology and Water Quality, May 12-14, 2003, Kansas City, MO.: Middleburg, VA., American Water Resources Association, AWRA Technical Publication Series No. TPS-03-1.

Duan, N., 1983, Smearing estimate-A nonparametric retransformation method: Journal of the American Statistical Association, v. 78, p. 605-610.

Emerson, D.G., 2005, Historic and naturalized monthly streamflow for selected sites in the Red River of the North Basin in North Dakota, Minnesota, and South Dakota, 1931-2001: U.S. Geological Survey Scientific Investigations Report 2005-5092, 228 p., accessed April 4, 2007, at http://pubs.water.usgs.gov/sir2005-5092/

Guenthner, R.S., 1991, Methods for estimating monthly mean concentrations of selected water-quality constituents for stream sites in the Red River of the North Basin, North Dakota and Minnesota: U.S. Geological Survey Water-Resources Investigations Report 91-4086, 113 p., accessed April 4, 2007, at http://pubs.er.usgs.gov/pubs/wri/ wri914086

Helsel, D.R., and Hirsch, R.M., 1995, Statistical methods in water resources: New York, Elsevier Science B.V., 529 p.

Hem, J.D., 1985, Study and interpretation of the chemical characteristics of natural water, ( $3 \mathrm{~d}$ ed.): U.S. Geological Survey Water-Supply Paper 2254, 264 p., accessed March 7, 2006, at http://pubs.er.usgs.gov/usgspubs/wsp/wsp2254

Insightful Corporation, 2001a, Resampling techniques-Bootstrap and jackknife, in S-PLUS 6 for Windows guide to statistics, v. 2: Seattle, Insightful Corporation, p. 537-562.

Insightful Corporation, 2001b, S-PLUS 6 for Windows user's guide: Seattle, Insightful Corporation, 688 p.

Insightful Corporation, 2005, S-PLUS language reference, in S-PLUS 7.0 for Windows professional developer; Seattle, Insightful Corporation [variously paged].
Kennedy, E.J., 1983, Computation of continuous records of streamflow: U.S. Geological Survey Techniques of Water-Resources Investigations, book 3, chap. A13, 53 p., accessed June 2, 2006, at http://pubs.usgs.gov/twri/twri3a13/

Kennedy, E.J., 1984, Discharge ratings at gaging stations: U.S. Geological Survey Techniques of Water-Resources Investigations, book 3, chap. A10, 59 p., accessed June 2, 2006, at http://pubs.usgs.gov/twri/twri3-a10/

Neter, J., Kutner, M.H., Nachtsheim, C.J., and Wasserman, W., 1996, Applied linear statistical models (4th ed.): Boston, WCB/McGraw-Hill, 1,408 p.

North Dakota Department of Health, 2003a, North Dakota Department of Health Chemistry Division quality assurance plan: Bismarck, North Dakota Department of Health [variously paged].

North Dakota Department of Health, 2003b, North Dakota Department of Health environmental methods manual: Bismarck, North Dakota Department of Health [variously paged].

North Dakota Department of Health, 2006, How minerals affect water supplies: Miscellaneous publication, about $3 \mathrm{p}$., accessed June 9, 2006, at http://www.health.state.nd.us/WQ/ GW/pubs/mineral.htm

North Dakota State Water Commission [n.d.], Devils Lake quick facts: accessed July 28, 2006, at http://www.swc.state. nd.us/4DLink9/4dcgi/GetContentPDF/PB-206/DL_Quick_ Facts.pdf

North Dakota State Water Commission [n.d.], Devils Lake flooding -Outlet: accessed July 28, 2006, at $h t t p: / / w w w$. swc.state.nd.us/4dlink9/4dcgi/GetSubCategoryRecord/ Devils\%20Lake\%20Flooding/Outlet

Rasmussen, T.J., Ziegler, A.C., and Rasmussen, P.P., 2005, Estimation of constituent concentrations, densities, loads, and yields in lower Kansas River, northeast Kansas, using regression models and continuous water-quality monitoring, January 2000 through December 2003: U.S. Geological Survey Scientific Investigations Report 2005-5165, 126 p., accessed April 24, 2007, at http://pubs.usgs. gov/sir/2005/5165/

Ryberg, K.R., 2006, Continuous water-quality monitoring and regression analysis to estimate constituent concentrations and loads in the Red River of the North, Fargo, North Dakota, 2003-05: U.S. Geological Survey Scientific Investigations Report 2006-5241, 35 p., accessed April 24, 2007, at $h t t p: / / p u b s . w a t e r . u s g s . g o v / S I R 20065241$ 
U.S. Army Corps of Engineers, 2005, Lake Ashtabula-Baldhill Dam-Valley City, North Dakota: U.S. Army Corps of Engineers brochure [variously paged], accessed March 14, 2007, at http://www.mvp.usace.army. mil/docs/rec/ashtabula.pdf

U.S. Geological Survey [variously dated], National field manual for the collection of water-quality data: U.S. Geological Survey Techniques of Water-Resources Investigations, book 9, chaps. A1-A9, [variously paged], accessed June 2, 2006, at http://pubs.water.usgs.gov/twri9A

Wagner, R.J., Boulger, R.W., Jr., Oblinger, C.J., and Smith, B.A., 2000, Guidelines and standard procedures for continuous water-quality monitors-Station operation, record computation, and data reporting: U.S. Geological Survey Techniques and Methods 1-D3 [variously paged], accessed April 11, 2007, at http://pubs.usgs.gov/tm/2006/tm1D3/

Williams-Sether, T.J., 2004, Regression equations for estimating concentrations of selected water-quality constituents for selected gaging stations in the Red River of the North Basin, North Dakota, Minnesota, and South Dakota: U.S. Geological Survey Water-Resources Investigations Report 03-4291, 33 p., accessed April 26, 2006, at http://pubs.water.usgs. gov/wri034291/

YSI Incorporated, 2006, 6-Series multiparameter water quality sondes user manual: Yellow Springs, Ohio, YSI Incorporated, 372 p., accessed April 9, 2007, at https://www.ysi. com/DocumentServer/DocumentServer?docID=EMS_FULL

Prepared by the Helena Publishing Service Center.

For more information concerning the research in this report, contact:

Director, U.S. Geological Survey

North Dakota Water Science Center

821 East Interstate Avenue

Bismarck, North Dakota 58503

(701) 250-7400

http://nd.water.usgs.gov/ 
6 Printed on recycled paper 